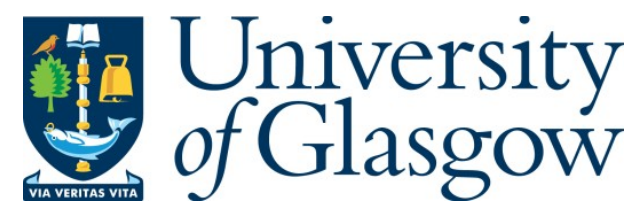

Reade, H. et al. (2020) Deglacial landscapes and the Late Upper Palaeolithic of Switzerland. Quaternary Science Reviews, 239, 106372.

(doi: 10.1016/j.quascirev.2020.106372)

There may be differences between this version and the published version. You are advised to consult the publisher's version if you wish to cite from it.

http://eprints.gla.ac.uk/218464/

Deposited on: 17 June 2020

Enlighten - Research publications by members of the University of Glasgow http://eprints.gla.ac.uk 


\section{Deglacial landscapes and the Late Upper Palaeolithic of Switzerland}

2

3

4

5

6

7

Hazel Reade ${ }^{1^{*}}$, Jennifer A. Tripp ${ }^{1,7}$, Sophy Charlton ${ }^{2,8}$, Sonja B. Grimm ${ }^{1,3}$, Denise Leesch ${ }^{4}$, Werner Müller ${ }^{4}$, Kerry L. Sayle ${ }^{5}$, Alex Fensome', Thomas F.G. Higham6 ${ }^{6}$ lan Barnes², Rhiannon E. Stevens ${ }^{1}$

${ }^{1}$ UCL Institute of Archaeology, 31-34 Gordon Square, London, WC1H OPY, United Kingdom

${ }^{2}$ Department of Earth Sciences, Natural History Museum, Cromwell Road, London SW7 5BD, United Kingdom

${ }^{3}$ Centre for Baltic and Scandinavian Archaeology (ZBSA), Foundation Schleswig-Holsteinian State Museums Schloss Gottorf, Schlossinsel 1, 24837 Schleswig, Germany

${ }^{4}$ Université de Neuchâtel, Laboratoire d'archéozoologie, Avenue de Bellevaux 51, CH-2000 Neuchâtel, Switzerland

${ }^{5}$ Scottish Universities Environmental Research Centre, Rankine Avenue, East Kilbride G75 OQF, United Kingdom

${ }^{6}$ Research Laboratory for Archaeology and the History of Art, University of Oxford, Dyson Perrins Building, South Parks Road, Oxford OX1 3QY, United Kingdom

"corresponding author: h.reade@ucl.ac.uk, +44(0)20 76791530

present addresses:

${ }^{7}$ Department of Chemistry, University of San Francisco, 2130 Fulton Street, San Francisco, CA 94117, USA

${ }^{8}$ PalaeoBARN, School of Archaeology, 1 South Parks Road, Oxford, OX1 3TG, United Kingdom 


\section{Abstract:}

The presence of people in Switzerland in recently deglaciated landscapes after the

29 Last Glacial Maximum represents human utilisation of newly available environments.

30 Understanding these landscapes and the resources available to the people who exploited

31 them is key to understanding not only Late Upper Palaeolithic settlement in Switzerland, but

32 more broadly human behavioural ecology in newly inhabited environmental settings. By

33 applying bone collagen stable isotope analysis $\left(\delta^{13} \mathrm{C}, \delta^{15} \mathrm{~N}\right.$ and $\left.\delta^{34} \mathrm{~S}\right)$ to faunal remains from

34 Late Upper Palaeolithic localities in Switzerland, we investigate animal ecology and

35 environmental conditions during periods of human occupation. High and relatively uniform

$36 \delta^{34} S$ values indicate that landscapes north of the Jura Mountains provided comparatively

37 stable environmental conditions, while lower and more variable $\delta^{34} S$ values on the Swiss

38 Plateau suggest a dynamic landscape with diverse hydrological and pedological conditions,

39 potentially linked to regionally different patterns of permafrost thaw. This contrasts with the

40 archaeological record that appears relatively uniform between the two regions, suggesting

41 people were employing similar subsistence behaviours across a range of environmental

42 settings. The pattern of change in $\delta^{15} \mathrm{~N}$ across the deglacial period appears consistent

43 between areas that remained ice-free throughout the LGM and those that were glaciated.

44 Most notable is a period of exclusively low $\delta^{15} \mathrm{~N}$ values between 15,200 and 14,800 cal. BP,

45 which could relate a regional expansion of floral biomass in response to environmental

46 change.

48 Keywords: Magdalenian, collagen, sulphur isotopes, nitrogen isotopes, carbon isotopes,

49 Pleistocene, palaeogeography, Europe, horse, reindeer 


\section{Introduction}

The period after the Last Glacial Maximum (LGM) in Switzerland saw significant expansion of human settlement into previously ice-covered landscapes. This was facilitated by the rapid development of pioneer floral and faunal communities, and most likely by changes in the range dynamics of key prey species, such as horse (Equus sp.) and reindeer (Rangifer tarandus) (Leesch et al., 2012; Cupillard et al., 2015). Understanding the environmental developments that drove such changes is key to interpreting the subsistence and settlement patterns of the human populations in this region and, more broadly, to investigating human behavioural ecology in newly available landscapes. Here we examine post-LGM paleoenvironmental conditions at two archaeological localities; Kastelhöhle-Nord (Figure 1), which is situated north of the Jura Mountains and remained ice-free throughout the LGM, and Monruz and Champréveyres (Figure 1), which are situated on the Swiss Plateau and became ice-free before 17,500 cal. BP (Ivy-Ochs et al., 2004). Bone collagen stable isotope analyses $\left(\delta^{13} \mathrm{C}, \delta^{15} \mathrm{~N}\right.$, and $\left.\delta^{34} \mathrm{~S}\right)$ are applied to the archaeological faunal assemblages from these sites to provide a direct record of past prey species ecology and environmental conditions during the period of human activity. New radiocarbon dates are also obtained from the fauna to better contextualise the chronology of human occupation. By combining this data with other published results, the pattern of post-LGM environmental change is compared between regions that remained ice-free throughout the LGM and those that were glaciated.

\subsection{Post-LGM environment and archaeology in Switzerland}

Switzerland during the LGM was almost entirely covered by ice with only a small region north of the Jura Mountains remaining unglaciated (Ivy-Ochs et al., 2004; Bini et al., 2009; Ivy-Ochs 2015;). While a brief phase of human occupation during the LGM occurred in the ice-free region (Terberger and Street, 2002; Reade et al., 2020), it is not until after the LGM that evidence of widespread and sustained Late Upper Palaeolithic human activity becomes apparent (Leesch et al., 2012). Post-LGM ice sheet decay in Switzerland was rapid, and the entire central Swiss Plateau was ice free before the onset of Greenland Stadial 2.1a (GS-2.1a, c.17,450 - 14,650 BP, Figure 2; Ivy-Ochs et al., 2004; Rasmussen et al., 2014). The exposure of new landscapes during Greenland Stadial 2.1b (GS-2.1b, c. 20,850 to 17,450 BP, Figure 2; Rasmussen et al., 2014) was quickly followed by the development of pioneer floral communities. Vegetation on the northern margins of the Jura Mountains was dominated by Poaceae, Artemisia, Juniperus and Hippophae (Cupillard et al., 2015), while species-rich treeless steppe tundra had developed on the Swiss Plateau by around 18,700 cal. BP (Rey et al., 2017). This was followed by an increase in herbaceous vegetation (e.g. Ammann and Lotter, 1989; Lotter, 1999; Wehrli et al., 2007) that allowed 
large herbivores to recolonise deglaciated regions by around 17,000 cal. BP (Morel and Hug, 1996; Hajdas et al., 2007).

There is some evidence for a relatively early phase of post-LGM human activity early in GS-2.1a, but the main expansion of settlement in Switzerland did not occur until the latter part of GS-2.1a (Weniger, 1989; Napierala, 2008; Leesch et al., 2012; Maier, 2015). These sites, associated with the Magdalenian culture, are characterised by a dominance of horse and reindeer in their faunal assemblages (Leesch et al., 2012; Nielsen, 2013; Maier, 2015). Attributed to Magdalenian techno-complexes $\mathrm{D}$ and $\mathrm{E}$, the sites cover a wide geographic distribution across the Swiss Plateau and Jura region, indicating the exploitation of a variety of landscapes (Leesch et al., 2012). Archaeological evidence comes from both caves and rockshelters, such as at Kesslerloch and Kastelhöhle-Nord, and open-air localities, such as the sites of Monruz and Champréveyres (Leesch et al., 2019). Coleoptera-based temperature estimates suggest summer and winter mean air temperatures on the Swiss Plateau during GS-2.1a were around $9^{\circ} \mathrm{C}$ and $-20^{\circ} \mathrm{C}$ respectively (Coope et al., 2000; Thew et al., 2009), while summer temperatures of around $12^{\circ} \mathrm{C}$ are estimated for the region north of the Jura mountains (Cupillard et al., 2015). Pollen and plant macrofossil evidence attest to vegetation rapidly increasing in diversity, but still dominated by cold-tolerant herbaceous species (Thew et al., 2009; Cupillard et al., 2015).

The onset of Greenland Interstadial 1 (GI-1, c. 14,650 to 12,850 BP, Figure 2; Rasmussen et al., 2014) corresponds to a rapid rise in temperatures on the Swiss Plateau and the expansion of juniper and birch vegetation into open shrub and grasslands (Thew et al., 2009). It is currently not clear whether Magdalenian activity continued into this early phase of $\mathrm{Gl}-1 \mathrm{e}$ or ended with the onset of this warm period, but by c. 14,400 cal. BP Azilian occupation of the Swiss Plateau was established (Leesch et al., 2012). During this time, mean summer and winter temperatures are estimated to have been around $15^{\circ} \mathrm{C}$ and $0^{\circ} \mathrm{C}$ respectively, with vegetation composed of a mosaic of open birch woodland, patches of dwarf birch and shrubs, and areas of grasses and sedges (Leesch, 1997; Thew et al., 2009). These more temperate conditions are reflected in the change in subsistence focus, with red deer (Cervus elaphus) and horse being important prey species (Leesch et al., 2004; Nielsen, 2013; Maier, 2015).

Considering the availability of different prey species and the ecologies and environments they represent is key to understanding the landscapes past people would have experienced. Whilst there is a wealth of Swiss Lateglacial palaeoenvironmental data from numerous lake and mire archives (e.g. Lotter, 1999; Coope et al., 2000; Wehrli et al. 2007; Lotter et al., 2012; Cupillard et al., 2015; Rey et al., 2017), analysis of the archaeological faunal assemblage provides the means to directly link inferences on habitat, ecology, and palaeoenvironmental conditions, to human hunting, settlement and subsistence practices. 


\subsection{Paleoenvironmental records from faunal stable isotopes}

Palaeoenvironmental and ecological data can be obtained directly from skeletal

128 remains of prey species from archaeological contexts through stable isotope analyses (e.g.

129 Stevens and Hedges, 2004; Stevens et al., 2008, 2014; Drucker et al., 2011a; 2011b; 2012;

130 Bocherens et al., 2015; Jones et al., 2018; Reade et al., 2020). In this study we use carbon

$131\left(\delta^{13} \mathrm{C}\right)$, nitrogen $\left(\delta^{15} \mathrm{~N}\right)$ and sulphur $\left(\delta^{34} \mathrm{~S}\right)$ isotope ratios in bone collagen to explore post-

132 LGM environments and prey species ecology in Switzerland. The measured isotopic signals

133 are underpinned by dietary specialisation, animal behaviour and environmental conditions.

$134 \quad$ Bone collagen $\delta^{13} \mathrm{C}$ values are largely determined by species-specific dietary

135 behaviours, such as grazing versus browsing, or specific dietary specialisations, such as the

136 consumption of lichens by reindeer, which leads to systematically higher $\delta^{13} \mathrm{C}$ values in

137 comparison to other herbivore species (Drucker et al., 2010; Bocherens et al., 2015).

138 However, dietary $\delta^{13} \mathrm{C}$ values also reflect atmospheric $\mathrm{CO}_{2}$ concentration and $\delta^{13} \mathrm{C}$,

139 environmental variables such as temperature and moisture availability, and vegetation

140 density and type (Heaton, 1999; Stevens and Hedges, 2004; Drucker et al., 2008; Kohn,

$1412010)$. Faunal $\delta^{15} \mathrm{~N}$ values are linked to both dietary specialisation/niche position and to

142 climatic parameters, such as temperature and precipitation, mediated through soil processes

143 (Amundson et al., 2003; Stevens et al., 2008; 2014; Drucker et al., 2011b; 2012; 2018

144 Craine et al 2015; Rabanus-Wallace et al., 2017). In particular, nutrient availability and

145 microbial activity may be reflected in herbivore bone collagen $\delta^{15} \mathrm{~N}$ values, parameters that

146 were likely strongly influenced by the presence of permafrost and ice sheets in the European

147 Lateglacial (Stevens and Hedges, 2004; Stevens et al., 2008; Drucker et al., 2011b).

148 Collagen $\delta^{34} \mathrm{~S}$ values relate to the soil environment upon which the animal fed. Bioavailable

149 sulphur can be derived from sulphates in groundwater and rain, atmospheric sulphur, and

150 from mineral weathering of the underlying geology (Nehlich, 2015). As such, bone collagen

$151 \quad \delta^{34} S$ values are spatially variable and often considered a tool for exploring mobility and

152 landscape utilisation (e.g. Drucker et al., 2012; 2018; Jones et al., 2018; Wißing et al., 2019).

153 However, bone collagen $\delta^{34} S$ values may also hold significant promise as a

154 palaeoenvironmental proxy, as soil-bedrock interactions, mineral weathering, and sulphur

155 cycling in the soil are driven by hydrological and microbial processes (Thode, 1991). These

156 are dynamic systems influenced by climatic and environmental conditions, such that $\delta^{34} S$

157 values in the local landscape are unlikely to have remained static across major

158 environmental transitions, for example the last deglaciation.

159

\section{2. Materials and Methods}


In this study we present $\delta^{13} \mathrm{C}, \delta^{15} \mathrm{~N}$ and $\delta^{34} S$ data generated from horse, reindeer, red deer and Bos/Bison bone collagen samples from the Swiss sites of Kastelhöhle-Nord,

163 Monruz and Champréveyres to explore animal ecology and environmental conditions after 164 the LGM.

\subsection{Archaeological samples}

The faunal assemblage from Kastelhöhle-Nord provides a record from the ice-free region of Switzerland, on the north edge of the Jura Mountains. Excavation of the cave between 1948 and 1954 revealed an 'intermediate' horizon associated with a Badegoulian phase of occupation, dated to the latter part of the LGM (Terberger and Street, 2002; Reade et al., 2020), and a $25 \mathrm{~cm}$-thick 'upper' horizon associated with the post-LGM Magdalenian (Leesch et al., 2012). This upper horizon contained a rich lithic assemblage that certainly represents more than one phase of Magdalenian activity at the site and most likely comprises more than one techno-complex (Magdalenian D-a and E; Leesch et al., 2012). A relatively long duration of accumulation for this horizon was confirmed by three faunal radiocarbon dates, which range from 16,350-15,965 cal. BP (ETH-45024) to 14,265-13,967 cal. BP (ETH-45026) (Leesch et al., 2012; Figure 2, Table 1). We sampled the large herbivore species found within the upper horizon (Schweizer, 1959); reindeer $(n=10)$, horse $(n=5)$ and Bos/Bison $(n=6)$. Of these, one reindeer bone displayed evidence of anthropogenic impact (cut marks). To investigate the chronology of this horizon, 3 specimens (two horse and the cut-marked reindeer bone) were selected for radiocarbon dating. The three specimens that had previously been dated (two reindeer, one Bos/Bison) were also re-dated to ensure methodological consistency between laboratories. the LGM, come from the open-air localities of Monruz and Champréveyres. Excavated between 1984 and 1992, both sites produced Late Upper Palaeolithic Magdalenian and Azilian occupation horizons, with rich faunal, botanical and lithic assemblages. Phases of

188 Magdalenian activity at the sites date to the later part of GS-2.1a and were focused primarily

189 on the exploitation of horse, together with a broad spectrum of smaller mammals, birds and

190 fish, particularly in spring and summer (Müller et al., 2006; Müller, 2013). Three horse bones

191 from these assemblages have previously been radiocarbon dated, producing age determinations between 15,874-15,349 cal. BP (OxA-20699) and 15,585-15,053 cal. BP (OxA-20701) (Figure 2, Table 1). We selected five reindeer and 12 horse samples from

194 Monruz (all from Magdalenian sector 1) and 7 red deer samples from Champréveyres (four

195 from Magdalenian sector 2, two from Azilian sector 1, and one from sector 2 where the 196 association to the Magdalenian or Azilian was uncertain) for stable isotope analysis. While 197 the specimens do not bear direct traces of anthropogenic action, the large herbivore faunal 
assemblage from the sites is confidently interpreted as the product of human action (Müller et al., 2006; Müller, 2013). While Magdalenian activity has been dated both from faunal and charcoal remains, dating of the Azilian phase has so far relied solely on charcoal samples. Therefore, one bone from the Azilian concentration at Champréveyres was selected for radiocarbon dating as part of this study.

\subsection{Sample pre-treatment}

A small sample of bone ( 0.2 to $1.3 \mathrm{~g}$ ) was collected from each specimen using a dental drill with either a small cutting wheel or tungsten burr attachment. Samples were prepared at University College London (UCL) using a modified version of the Oxford Radiocarbon Accelerator Unit (ORAU) collagen extraction procedures (AF and AG methods; Brock et al., 2010), which is based on a modified version of the Longin (1971) method. All samples were treated with $0.5 \mathrm{M}$ hydrochloric acid $(\mathrm{HCl})$ at $4^{\circ} \mathrm{C}$ until fully demineralised and then thoroughly rinsed with ultrapure water. Some samples were then also treated with $0.1 \mathrm{M}$ sodium hydroxide (30mins), and $0.5 \mathrm{M} \mathrm{HCl}(1 \mathrm{hr})$ to remove humic contaminants (Szpak et al., 2017), again being thoroughly rinsed with ultrapure water between reagents. All samples were then gelatinised in $\mathrm{pH} 3 \mathrm{HCl}$ solution at $75^{\circ} \mathrm{C}$ for $48 \mathrm{hrs}$ and filtered using a pre-cleaned Ezee-filter. For most samples, including all those to be radiocarbon dated, the filtrate was then passed through a pre-cleaned 15-30 kD ultrafilter, with the $>30 \mathrm{kD}$ fraction collected and freeze-dried (AF method). For some samples the ultrafiltration step was omitted (AG method); while ultrafiltration has been shown to successfully improve the removal of contaminants that can influence radiocarbon determinations (Higham et al., 2006), it also significantly reduces collagen yield, while at the same time producing little difference in measured stable isotope compositions (Sealy et al., 2014; Szpak et al., 2017). Details of pretreatment methodology are given for each sample in the supplementary information S1.

\subsection{Stable isotope analysis}

Collagen yields from Kastelhöhle-Nord ranged from 2.3 to $16.2 \%$. Collagen preservation at Monruz and Champréveyres was poorer; 12 out of 24 samples failed to produce enough collagen for stable isotope analysis (yields $\leq 0.7 \%$ ), while the other 12 samples had collagen yields ranging from 0.8 to $3.6 \%$ (supplementary information $\mathrm{S} 1$ ). Samples with adequate collagen were analysed for their nitrogen $\left(\delta^{15} \mathrm{~N}\right)$, carbon $\left(\delta^{13} \mathrm{C}\right)$, and sulphur $\left(\delta^{34} S\right)$ isotopic ratios at the Scottish Universities Environmental Research Centre (SUERC). 1.2-1.5mg aliquots of freeze-dried collagen were weighed into tin capsules and analysed using a Delta $V$ Advantage continuous-flow isotope ratio mass spectrometer coupled via a ConfloIV to an EA IsoLink elemental analyser (Thermo Fisher Scientific, Bremen). For every ten archaeological samples, three in-house standards, calibrated to the 
International Atomic Energy Agency (IAEA) reference materials, were analysed (Sayle et al., 2019). Results are reported as per mil (\%o) relative to the internationally accepted standards VPDB, AIR and VCDT. Measurement uncertainty was determined to be $\pm 0.1 \%$ for $\delta^{13} \mathrm{C}$, $\pm 0.2 \%$ for $\delta^{15} \mathrm{~N}$, and $\pm 0.3 \%$ for $\delta^{34} \mathrm{~S}$, on the basis of repeated measurements of an in-house bone collagen standard and a certified fish gelatin standard (Elemental Microanalysis, UK).

240 Standard quality control criteria were used to assess the $\delta^{13} \mathrm{C}, \delta^{15} \mathrm{~N}$ and $\delta^{34} \mathrm{~S}$ data (DeNiro, 1985; Ambrose, 1990; Nehlich and Richards, 2009). Each sample was analysed in duplicate and reproducibility was better than $\pm 0.1 \%$ for $\delta^{13} \mathrm{C}, \pm 0.2 \%$ for $\delta^{15} \mathrm{~N}$ and $\pm 0.3 \%$ for $\delta^{34} \mathrm{~S}$. All analysed samples had C:N atomic ratios between 3.2-3.6, and \% $\mathrm{C}$ and $\% \mathrm{~N}$ between $35-$ $46 \%$ and $12-16 \%$, respectively, indicating good bone collagen preservation (DeNiro, 1985; Ambrose, 1990). All analysed samples except UPN-240 had C:S and N:S atomic ratios within the recommended ranges of $600 \pm 300$ and $200 \pm 100$, and \%S content between 0.14 and $0.30 \%$ (Nehlich and Richards, 2009)

\subsection{Radiocarbon analysis and background corrections}

Radiocarbon dating was performed at ORAU using their standard procedures, as described by Brock et al. (2010). For each sample, approximately $5 \mathrm{mg}$ of dry collagen, which had been weighed into tin capsules baked at $500^{\circ} \mathrm{C}$ for 12 hours, was combusted using an elemental analyser coupled to an isotope ratio mass spectrometer, employing a splitter to allow for collection of the $\mathrm{CO}_{2}$ (Bronk Ramsey and Humm, 2000; Brock at al., 2010). Samples were graphitised by reduction of collected $\mathrm{CO}_{2}$ over an iron catalyst in an excess $\mathrm{H}_{2}$ atmosphere at $560^{\circ} \mathrm{C}$ (Bronk Ramsey and Hedges, 1997; Dee et al., 2010). ${ }^{14} \mathrm{C}$ dates were measured on the Oxford AMS system using a cesium ion source for ionisation of the solid graphite sample (Bronk Ramsey et al., 2004). To denote the bone pretreatment at UCL rather than at ORAU, all measured dates were given "OxA-V-wwww-pp" numbers, where "wwww" indicates the wheel number, and "pp" is the position of the sample on the wheel (Brock et al., 2010). As collagen extraction was performed at UCL according to the ORAU pretreatment protocol, background corrections were applied to our dates based on repeat AMS measurements at ORAU of known-aged reference samples prepared in the UCL laboratory, following the method outlined by Wood et al. (2010). A full description of our correction methodology is detailed in Reade et al. (2020). Corrected dates are denoted by adding a " $\mathrm{C}$ " to the end of the date code assigned by ORAU. Uncorrected measured date values as well as further details of the correction calculations are provided in the supplemental information S2.

\section{Results and Discussion}




\section{Champréveyres}

Six new radiocarbon determinations were made on fauna from the upper horizon at Kastelhöhle-Nord (Figure 2, Table 1). Three of these were undertaken on previously dated specimens for inter-laboratory comparison, and the results reflect those previously obtained (Leesch and Müller, 2012) (Table 1). The new dates for Kastelhöhle-Nord's upper horizon range from 13,550 $\pm 60{ }^{14} \mathrm{C} \mathrm{BP}\left(\mathrm{OxA}-\mathrm{V}-2794-25 \mathrm{C}\right.$ ) to $12,200 \pm 50{ }^{14} \mathrm{C} \mathrm{BP}$ (OxA-V-2793$56 C)$, giving a range of calibrated ages between 16,350 - 15,965 cal. BP and 14,260 13,935 cal. BP, further confirming an extended period of bone accumulation in the horizon. There appears to be a species-based chronological pattern to the results (Figure 2); Bos/Bison and horse date to GS-2.1a and reindeer to GI-1. However, this finding is likely coincidental as reindeer dating to GS-2.1a are known at other sites within the same valley system (e.g. Hollenberg-Höhle 3; Müller and Leesch, 2011), as are horse dating to GI-1 (e.g. Kohlerhöhle; Leesch and Müller, 2012). Thus, both species were present within the local landscape at the same time as one another.

Archaeologically, the dating of a cut-marked reindeer bone found in association with Magdalenian artefacts to the later, colder part of $\mathrm{Gl}-1$ ed is problematic when considered against our current understanding of the chronology of Magdalenian/Azilian development and their subsistence systems in the region. While it is recognised that the Kastelhöhle-Nord upper horizon lithic assemblage most probably represents more than one Magdalenian techno-assemblage (Leesch et al., 2012), the reindeer date is significantly later than those at other Magdalenian sites in the region and also later than dates associated with the Early Azilian assemblages at Monruz and Champréveyres. Therefore, it appears reindeer hunting at Kastelhöhle-Nord continued or resumed after the Magdalenian disappeared from the archaeological record in adjacent regions. As the bone was found in the mixed Magdalenian techno-assemblage the question arises whether this lithic tradition survived or was revived with the hunting of reindeer during $\mathrm{Gl}-1 \mathrm{ed}$, or whether there is a yet unrecognised lithic assemblage type admixed in the upper horizon. Comparable late $\mathrm{Gl}-1$ ed radiocarbon dates on faunal remains (horse, ptarmigans, red deer and dog) have come from the nearby cave of Büttenloch, and from other northern Swiss localities, namely Rislisberghöhle and Kesslerloch (Napierala, 2008; Leesch and Müller, 2012). Chronologically, the dates are compatible with the Azilian phase in Switzerland, although the dated fauna cannot be certainly attributed to the subsistence activities of this culture. horizon at Champréveyres, which had so far been chronologically constrained by radiocarbon determinations made on charcoal and macrobotanical remains (Leesch, 1997).

308 The date, $12,480 \pm 50{ }^{14} \mathrm{C}$ years BP (OxA-V-2754-49C, Figure 2, Table 1), falls within the 
309 range of dates on charcoal from hearth deposits, confirming the contemporaneity of the

310 faunal assemblage with human activity at the site.

$312 \quad 3.2$ Lateglacial ecology and environment at Kastelhöhle-Nord and

\section{Monruz/Champréveyres}

314 Kastelhöhle-Nord upper horizon $\delta^{13} \mathrm{C}$ values overlap for reindeer and Bos/Bison, ($31520.3 \%$ o to $-19.4 \%$ and $-20.1 \%$ o to $-19.7 \%$, respectively) while horse $\delta^{13} \mathrm{C}$ values differ (-

$31621.3 \%$ to $-20.2 \%$ ) (Figure 3, Table 2). A similar offset between reindeer and Bos/Bison, and

317 horse is also observed in the nitrogen isotopic data, which ranges from $0.7 \%$ o to $2.3 \%$ for

318 horse, compared to $2.3 \%$ to $3.5 \%$ and $2.6 \%$ to $4.0 \%$ for reindeer and Bos/Bison

319 respectively (Figure 3, Table 2). The significant species-based differences between $\delta^{13} \mathrm{C}$ and

$320 \quad \delta^{15} \mathrm{~N}$ values (Figure 3, supplementary information S3.1 and S3.2) can largely be explained

321 by species ecology and dietary specialisation. The comparable Bos/Bison and reindeer $\delta^{13} \mathrm{C}$

322 values indicate ecological overlap. Reindeer typically display higher $\delta^{13} \mathrm{C}$ values than other

323 herbivore species due to lichen consumption; this dietary behaviour has also been observed

324 in some modern bison populations and has previously been suggested for the species in

325 other Late Pleistocene contexts (Larter and Gates, 1991; Julien et al., 2012; Bocherens et

326 al., 2015). The two species also display similar $\delta^{15} \mathrm{~N}$ and $\delta^{34} S$ values (Figure 3, Table 2),

327 further supporting the interpretation of overlapping habitat preferences. Lower $\delta^{13} \mathrm{C}$ and $\delta^{15} \mathrm{~N}$

328 values in horse compared to reindeer is a pattern that is observed across Pleistocene

329 Europe and indicates occupation of a different ecological niche (Stevens and Hedges, 2004;

330 Stevens et al., 2008; Bocherens et al., 2015). The $\delta^{34} S$ values observed for horse also differ

331 from those of reindeer and Bos/Bison (Figure 3, Table 2), further suggesting that the animals

332 were not only occupying different niches, but also possibly different landscapes and/or

333 different topographical features/locations within a given area. However, it should be noted

334 that the species-dependent chronological pattern observed in the radiocarbon dates (Figure

335 2) means that it cannot be certainly demonstrated that any of the individuals analysed here

336 overlap in their chronology, and as such, the differences observed may partly be influenced

337 by temporally changing underlying environmental parameters. Pollen records indicate the

338 vegetation north of the Jura mountains was dominated by a mosaic of Poaceae, Artemisia,

339 Juniperus and Hippophae species during GS-2.1a, with Juniperus and Betula expanding at

340 the start of $\mathrm{Gl}-1 \mathrm{e}$, while climatic proxies suggest both an increase in temperature and

341 precipitation across this time interval (Cupillard et al., 2015). Thus, the observed isotopic

342 data likely represents a combined signal of environmental change and species-specific

343 patterns of habitat utilisation.

344 A similar pattern of variation between horse and reindeer is seen in the Monruz

345 results (Figure 4). At this site average horse $\delta^{15} \mathrm{~N}$ values $\left(1.8 \pm 0.6 \%\right.$ ) and $\delta^{13} \mathrm{C}$ values (- 
$21.0 \pm 0.2 \%$ o $)$ are significantly different to the reindeer values $(2.8 \pm 0.2 \%$ and $-19.8 \pm 0.2 \%$, respectively) (S3.3). Furthermore, $\delta^{13} \mathrm{C}$ and $\delta^{15} \mathrm{~N}$ values for horse at Monruz and

348 Kastelhöhle-Nord upper horizon are indistinguishable from one another; the same is also

349 observed for reindeer from the two sites (S3.4 and S3.5). By contrast, horse and reindeer

$350 \quad \delta^{34} \mathrm{~S}$ values at Monruz are statistically indistinguishable from one another (Figure 4; S3.6),

351 but significantly different to those of the horse and reindeer at Kastelhöhle-Nord (S3.7).

352 Therefore, $\delta^{13} \mathrm{C}$ and $\delta^{15} \mathrm{~N}$ values cluster by species, indicating that ecological niche and

353 animal behaviour are the primary factors influencing these values, while $\delta^{34} S$ values cluster

354 by site, indicating that location-based factors are most strongly represented in the sulphur

355 isotope ratios. Almost twice as much variability is observed in the Monruz $\delta^{34} S$ values

$356(16.5 \%)$ than in the Kastelhöhle-Nord $\delta^{34} S$ values $(8.8 \%$ ), despite the Monruz samples

357 representing a significantly shorter time span (Figure 2) and representing only two, rather

358 than three, different animal species (Table 2). Further, unlike at Kastelhöhle-Nord, the horse

359 and reindeer $\delta^{34} \mathrm{~S}$ values from Monruz completely overlap with one another. Thus, while the

360 Monruz $\delta^{13} \mathrm{C}$ and $\delta^{15} \mathrm{~N}$ values suggest that horse and reindeer were occupying different

361 ecological niches, the sulphur isotopic data suggests this was likely taking place within the

362 same geographical region(s), and therefore under the same range of environmental and

363 climatic conditions. The large range in $\delta^{34} S$ values could indicate both species were

364 displaying a number of different long-distance mobility behaviours, or alternatively, could

365 suggest a high level of environmental variability within a relatively small geographical region.

366 As the Monruz horse produce a significantly greater range of $\delta^{34} S$ values $(16.2 \%)$ than the

367 reindeer $(7.0 \%)$, and unlike reindeer, horse generally do not undertake long-distance

368 seasonal migrations, we suggest the second interpretation is more plausible. However, we

369 recognise mobility behaviours may have differed between different environments in Late

370 Pleistocene Europe (e.g. Bignon et al., 2005; Pelligrini et al., 2008; Pryor et al., 2016).

371 The isotopic composition of bioavailable sulphur is spatially variable at a range of

372 scales. At the regional level, soil $\delta^{34} S$ values are controlled by location-based inputs from

373 underlying bedrock geology, sea spray and the atmosphere (Thode, 1991; Nehlich, 2015).

374 However, Monruz and Kastelhöhle-Nord are situated far from the coast and occupy similar,

375 relatively uniform sedimentary geologies comprised of limestone, sandstone, and clay that

376 are unlikely to account for the range of $\delta^{34} S$ values that we observe (Asch, 2005; Figure 1).

377 Other potential sources of spatial variation in $\delta^{34} S$ values relate to more local-scale

378 differences in soil microbial activity, influenced by soil temperature, water content and

379 oxygen availability (Orchard and Cook 1983; Liu et al., 2018; Nitsch et al., 2019). Indeed,

380 paleoenvironmental records from the Swiss Plateau document a highly heterogeneous

381 landscape existed during this period; increasing temperatures led to permafrost thaw,

382 terrestrial landscape instability and the development of localised marshy habitats in some 
areas, while in other areas it facilitated vegetation development and soil stabilisation (Thew et al., 2009; Rey et al., 2017; 2019). It is these local-scale processes which we suggest are represented in the high level of variation observed in the Monruz $\delta^{34} S$ values.

Only one result is available for the Azilian period from Monruz and Champréveyres. This was the sole sample from an Azilian context at Champréveyres to yield adequate collagen for analysis, and the only red deer sample in our data set. This sample produced $\delta^{13} \mathrm{C}$ and $\delta^{15} \mathrm{~N}$ values of $-20.6 \%$ and $2.4 \%$, respectively, which are comparable to the red deer previously analysed from the site (-20.6\%o and 3.4\%o, Drucker et al., 2009).

\section{Deglaciated versus unglaciated Lateglacial landscape development}

In the context of Late Pleistocene Europe, much of the spatial and temporal variation observed in herbivore bone collagen stable isotope values has been linked to soil processes, related to variations in temperature, permafrost extent and proximity to ice sheet margins (Stevens and Hedges, 2004; Stevens et al., 2008; Drucker et al., 2011b; 2012). To explore these possible drivers of the isotopic signatures, and by inference post-LGM environmental change, we compare the temporal patterns observed in fauna from neighbouring regions that had been glaciated at the LGM to those that had remained ice-free during the last glacial cycle. We combine the results of this study with those previously published from regions of Switzerland, the French Jura and Western Alps (Drucker et al., 2003; 2009; 2011a; 2011b; 2012; Stevens et al., 2008; Bocherens et al., 2011; Gröcke et al., 2017; Reade et al., 2020; Figure 5; Supplementary Information 5). Sites are assigned to two groups based on reconstructed maximum ice extents; those in locations that remained icefree through the LGM, and those that were ice-covered at the LGM (Campy, 1992; Bini et al., 2009; Schlüchter et al., 2010). As this analysis combines data from multiple species (Bos/Bison, horse, red deer, and reindeer), differences in dietary behaviours mask possible environmental interpretations from the $\delta^{13} \mathrm{C}$ values. Dietary ecology is also likely responsible for some of the scatter in the $\delta^{15} \mathrm{~N}$ data, but temporal trends are nonetheless apparent (Figure 5). Herbivore $\delta^{34} \mathrm{~S}$ values appear to primarily reflect the underlying environment, irrespective of differences in dietary ecology, and the different temporal patterns in the $\delta^{34} S$ values between the two location-based groups is striking (Figure 5).

For $\delta^{15} \mathrm{~N}$ values, the temporal pattern of variation appears consistent between the ice-covered and ice-free areas, suggesting that the presence/absence of ice sheets and processes of deglaciation are not the direct primary influences being recorded in the signal. The most notable aspect of the record is the absence of $\delta^{15} \mathrm{~N}$ values greater than c. $2.5 \%$ between around 15,200 and 14,800 cal. BP. As this pattern is present in samples that span a large geographical area, which is topographically and environmentally diverse, a regionalscale explanation should be sought. Low herbivore $\delta^{15} \mathrm{~N}$ values $(<2.5 \%$ o ) in Lateglacial 
420 Europe have previously been linked to environments with nutrient-poor soils, where low

421 temperatures and the presence of permafrost impeded the soil nitrogen cycle, or to

422 increased environmental moisture; conversely, high herbivore $\delta^{15} \mathrm{~N}$ values $(>5 \%$ ) have been

423 considered typical of environments where nitrogen supply is not a limiting factor to plant

424 growth and environmental conditions do not inhibit the soil nutrient cycle (Schulze et al.,

425 1994; Hobbie et al., 1998; Jonasson et al., 1999; Stevens and Hedges 2004; Stark, 2007;

426 Stevens et al., 2008; 2009; Drucker et al., 2011b; 2012; Rabanus-Wallace et al., 2017). Low

$427 \quad \delta^{15} \mathrm{~N}$ values occur alongside an absence of high $\delta^{15} \mathrm{~N}$ values at various points in the

428 Swiss/French record shown in Figure 5 (at c. 21,000 - 18,200 cal. BP, c. 15,200-14,800

429 cal. BP, and c. 12,200 cal. BP). However, we suggest that it is only the 15,200-14,800 cal.

430 BP interval that can be discussed with a degree of confidence, as the exclusively low $\delta^{15} \mathrm{~N}$

431 values during this time interval are clearly bounded by the presence of higher $\delta^{15} \mathrm{~N}$ values

432 both before and after (Figure 5). The timing of this disappearance of $\delta^{15} \mathrm{~N}$ values greater

433 than c. $2.5 \%$ in the Swiss/French record broadly corresponds to the end of Heinrich Event 1

434 (HE1), a period of climatic cooling following the LGM, during which Alpine ice sheets

435 expanded (Hemming, 2004; Ivy-Ochs et al., 2006). Immediately after HE1, a small but

436 significant climatic warming is evident, although lake level data suggests annual precipitation

437 amounts remained relatively low (Magny et al., 2006; Magny, 2013). On the Swiss Plateau

438 localised permafrost degradation and an increase in insect and plant species diversity is

439 evident (Thew et al., 2009; Rey et al., 2017). A similar increase in vegetation density is also

440 evident northwest of the Jura mountains (e.g. Magny et al., 2006). It is possible that if this

441 period corresponds to the first significant regional increase in vegetation after the LGM, such

442 an increase even if relatively small, occurring in an already nutrient-limited environment

443 would initially deplete nutrient availability even further. The effect of this would be a short-

444 term decline in average plant $\delta^{15} \mathrm{~N}$ values, followed by a rapid increase, as soils matured and

445 nutrient cycling accelerated (Hobbie et al., 1998; 2005; Ammann et al., 2013).

446 Unlike the nitrogen record, sulphur isotope ratios display a significantly different

447 pattern of change between ice-covered and ice-free areas. Ice-free areas display low $\delta^{34} S$

448 values (<-8\%) at around 23,000 cal. BP, but then remain consistently high across the

449 deglacial period (>-8\%o, except for one outlier). By contrast, in locations that were covered

450 by ice at the LGM, low $\delta^{34} \mathrm{~S}$ values (<-8\%) are recorded at around 15,900 to 15,400 cal. BP,

451 increasing to a minimum of $-5 \%$ by 15,000 cal. BP. While some of the scatter in the data

452 can be explained by different patterns of mobility between different species, such influences

453 cannot explain the clear location-specific differences in the temporal sulphur isotopic record.

454 Further, while location-based geological differences may produce different absolute $\delta^{34} S$

455 values, no relationship is observed between bedrock type, $\delta^{34} \mathrm{~S}$, and glaciated/ ice-free

456 location (Figure S4). As such, spatially and temporally variable environmental parameters 
need to be considered. Temperature-mediated controls on soil mineralisation and volatilisation, and bacterial reduction of sulphur have been suggested to explain temporal changes in herbivore $\delta^{34} S$ values (Drucker et al., 2011a). However, temperature change alone cannot explain the location-based differences we observe in the data, unless it was acting on a sub-regional scale. Soil maturity has also been linked to differences in herbivore sulphur isotopic ratios (Drucker et al., 2012), but this interpretation is not supported in this instance by the corresponding $\delta^{15} \mathrm{~N}$ values.

Here, we suggest that the herbivore $\delta^{34} S$ values reflect local soil conditions that are primarily related to hydrology and microbial activity. Plants acquire sulphur from the soil as sulphate, derived from mineral weathering and atmospheric deposition, and influenced by soil microbial action (Walker, 1957; Krouse, 1980; Robinson and Bottrell, 1997; Newton and Bottrell, 2007). Changing soil hydrological dynamics, particularly the development of waterlogged environments that result in anaerobic conditions, can lead to significant differences in plant $\delta^{34} S$ values brought about by changing bacteria-mediated fractionations (Fry et al., 1982; Trust and Fry, 1992; Groscheová et al., 2000; Nitsch et al., 2019). While the processes that govern soil $\delta^{34} S$ in relation to changing hydrological conditions are complex and not yet fully understood (Mandernack et al., 2000; Nitsch et al., 2019), we suggest that the different pattern observed between the ice-free and recently-deglaciated regions in postLGM Switzerland could relate to location specific hydrological dynamics, potentially related ice sheet melt, or more likely, permafrost thaw processes. Indeed, the palaeoenvironmental record from Lake Neuchâtel on the Swiss Plateau identifies a period of permafrost thaw coinciding with considerable instability of the terrestrial landscape and localised marshy conditions, that is largely contemporaneous with the low herbivore $\delta^{34} S$ values identified in this study at Monruz (Thew et al., 2009). By contrast, while there is greater debate about the distribution and character of permafrost north and west of the Jura, recent studies suggest that if present, it did not persist into the latter part of GS-2.1a (Renssen and Vandenberghe, 2003; Bertran et al., 2014; Vandenberghe et al., 2014). This could explain why low $\delta^{34} \mathrm{~S}$ values during GS-2.1a are not observed in these regions.

\section{Conclusion}

The carbon, nitrogen and sulphur isotopic ratios reported in this study attest to regionally variable environmental development in post-LGM Switzerland. Significant differences between areas that remained ice-free throughout the last glacial cycle and those that were glaciated at the LGM are identified. Deriving such information from archaeological faunal assemblages allows these environmental records to be directly related to human presence in these areas, and to subsistence and settlement strategies in such landscapes, 
which can more broadly inform on human behavioural ecology in peripheral settings. Our results show the post-LGM period in Switzerland and adjacent regions was characterised by diverse environmental conditions, indicating that a range of habitats and landscapes were available for humans and animals to exploit. Herbivore $\delta^{13} \mathrm{C}$ and $\delta^{15} \mathrm{~N}$ values are most strongly influenced by species ecology and dietary behaviours, underpinned by environmental influences. $\delta^{34} S$ values appear to most strongly correspond to locationspecific environmental conditions. Our results suggest that during the period of Magdalenian activity in Switzerland the Swiss Plateau was a dynamic and diverse landscape, while greater environmental stability may have existed north of the Jura Mountains.

The absence of high $\left(>2.5 \%\right.$ ) $\delta^{15} \mathrm{~N}$ values between 15,200 and 14,800 cal. BP, both on the Swiss Plateau and north of the Jura, indicates a regional-scale environmental phenomenon that we suggest is related to the combination of prolonged low temperatures, limited bioavailable soil nutrients, and elevated nutrient demand from increasing vegetation cover. In contrast, low $(<-8 \%) \delta^{34} S$ values occur at different times in different locations, and we suggest that these reflect locally variable hydrological dynamics, either related to changing rates of mineral weathering and soil-bedrock interactions or to changing soil redox conditions, which govern microorganism-mediated isotopic fractionations. We suggest that either interpretation is congruous with the regionally different patterns of ice sheet melt and permafrost thaw.

\section{Acknowledgements}

515 We thank the Archaeological Services of the cantons of Solothurn and Neuchâtel for 516 permitting sampling of the material included in this research. We are also grateful to the 517 Mary Rose Trust for their donation of cow ribs from the Mary Rose shipwreck, which 518 provided known-age standard material for radiocarbon analysis. Emily Walsh is thanked for 519 her assistance with the collagen extraction laboratory procedure. This research was funded 520 by a European Research Council Consolidator Grant awarded to Rhiannon Stevens (grant 521 ID: 617777).

\section{Author contributions}

524 Conceptualization: RES, HR, SG, TH \& IB; Sample collection: HR, SC, DL, WM; Formal 525 analysis: HR, JT, AF, \& KLS; Investigation: HR, JT \& RES; Supervision: RES; Writing 526 original draft: HR; Writing - review \& editing: all authors; Funding acquisition: RES.

\section{Reference:}

528 Ambrose SH (1990) Preparation and characterization of bone and tooth collagen for isotopic 529 analysis. J Archaeol Sci 17(4):431-451. https://doi.org/10.1016/0305-4403(90)90007-R 
Ammann B, Lotter AF (1989) Late-Glacial radiocarbon- and palynostratigraphy on the Swiss Plateau. Boreas 18:109-126. https://doi.org/10.1111/j.1502-3885.1989.tb00381.x

Ammann B, van Leeuwn JFN, van der Knapp WO, Lischke H, Heiri O, Tinner W. (2013) Vegetation responses to rapid warming and to minor climatic fluctuations during the Late-Glacial Interstadial (GI-1) at Gerzensee (Switzerland). Palaeogeogr Palaeocl 391:40-59. https://doi.org/10.1016/j.palaeo.2012.07.010.

Amundson R, Austin AT, Schuur EAG, Yoo K, Matzek V, Kendall C, Uebersax A, Brenner D, Baisden WT (2003) Global patterns of the isotopic composition of soil and plant nitrogen. Global Biogeochem Cy 17(1): 1031. https://doi.org/10.1029/2002GB001903

Asch K. (2005) IGME 5000: 1:5 Million International Geological Map of Europe and Adjacent Areas. BGR (Hannover).

Bertran P, Andrieux E, Antoine P, Coutard S, Deschodt L, Gardère P, Hernandez M, Legentil C, Lenoble A, Liard M, Mercier N, Moine O, Sitzia L, Van Vliet-Lanoë B (2014)

Distribution and chronology of Pleistocene permafrost features in France: database and first results. Boreas 43:699-711. https://doi.org/10.1111/bor.12025

Bignon O, Baylac M, Vigne J-D, Eisenmann V (2005) Geometric morphometrics and the population diversity of Late Glacial horses in Western Europe (Equua caballus arcelini): phylogeographic and anthropological implications. J Archaeol Sci 32(2):375391. https://doi.org/10.1016/j.jas.2004.02.016

Bini A, Buoncristiani J-F, Couterrand S, Ellwanger D, Fleber M, Florineth D, Graf HR, Keller O, Kelly M, Schlüchter C, Schoeneich P (2009) La Suisse durant le denier maximum glaciaire (LGM) 1:500000. Federal Office of Topography Swisstopo, Switzerland.

Bocherens H, Drucker DG, Taubald H (2011) Preservation of bone collagen sulphur isotopic compositions in an early Holocene river-bank archaeological site. Palaeogeogr Palaeocl 310(1-2):32-38. https://doi.org/10.1016/j.palaeo.2011.05.016

Bocherens H, Drucker DG, Germonpré M, Lázničková M, Naito WI, Wissing C, Brůžek J, Oliva M (2015) Reconstruction of the Gravettian food-web at Předmostí I using multiisotopic tracking $\left({ }^{13} \mathrm{C},{ }^{15} \mathrm{~N},{ }^{34} \mathrm{~S}\right)$ of bone collagen. Quatern Int 359-360:211-228. https://doi.org/10.1016/j.quaint.2014.09.044

Brock F, Higham TFG, Ditchfield P, Bronk Ramsey C (2010) Current pretreatment methods for AMS radiocarbon dating at the Oxford Radiocarbon Accelerator Unit (ORAU) Radiocarbon 52:103-112. https://doi.org/10.1017/S0033822200045069.

Bronk Ramsey C, Higham T, Leach P (2004) Towards High-Precision AMS: Progress and Limitations. Radiocarbon 46(1): 17-24. https://doi.org/10.1017/S0033822200039308 the two last Pleistocene glaciations. Palaeogeogr Palaeocl 93(1-2):1-12. https://doi.org/10.1016/0031-0182(92)90180-D 
Coope GR, Elias SA (2000) The environment of Upper Palaeolithic (Magdalenian and Azilian) hunters at Hauterive-Champréveyres, Neuchâtel, Switzerland, interpreted from coleopteran remains. J Quaternary Sci 15:157-175. https://doi.org/10.1002/(SICI)1099-1417(200002)15:2<157::AID-JQS478>3.0.CO;2-K

Craine JM, Elmore AJ, Wang L, Augusto L, Baisden WT, Brookshire ENJ, Cramer MD, Hasselquist NJ, Hobbie EA, Kahmen A, Koba K, Kranabetter JM, Mack MC, MarinSpiotta E, Mayor JR, McLauchlan KK, Michelsen A, Nardoto GB, Oliveira RS, Perakis SS, Peri PL, Quesada CA, Richter A, Schipper LA, Stevenson BA, Turner BL, Viani RAG, Wanek W, Zeller B (2015) Convergence of soil nitrogen isotopes across global

Cupillard C, Magny M, Bocherens H, Bridault A, Bégeot C, Bichet V, Bossuet G, Drucker DG, Gauthier E, Jouannic G, Millet L, Richard H, Ruis D, Ruffaldi P, Walter-Simonnet A-V (2015) Changes in ecosystems, climate and societies in the Jura Mountains between 40 and 8 ka cal BP. Quaternary Int 378:40-72. https://doi.org/10.1016/j.quaint.2014.05.032.

DeNiro MJ (1985) Postmortem preservation and alteration of in vivo bone collagen isotope ratios in relation to palaeodietary reconstruction. Nature 317:806-809. https://doi.org/10.1038/317806a0.

Drucker DG, Bocherens H, Bridault A, Billiou D (2003) Carbon and nitrogen isotopic composition of red deer (Cervus elaphus) collagen as a tool for tracking palaeoenvironmental change during the Late-Glacial and Early Holocene in the northern Jura (France). Palaeogeog Palaeocl 195:375-388. https://doi.org/10.1016/S0031-0182(03)00366-3.

Drucker DG, Bridault A, Hobson KA, Szuma E, Bocherens H (2008) Can carbon-13 in large herbivores reflect the canopy effect in temperate and boreal ecosystems? Evidence from modern and ancient ungulates. Palaeogeogr Palaeocl 266:69-82. https://doi.org/10.1016/j.palaeo.2008.03.020.

Drucker DG, Bocherens H, Billiou D (2009) Quelle valence écologique pour les rennes et autres cervidés au Tardiglaciaire dans les Alpes du nord et le Jura? Résultats de l'analyse des isotopes stables $\left({ }^{13} \mathrm{C},{ }^{15} \mathrm{~N}\right)$ du collagène, in: Pion $\mathrm{G}(\mathrm{Ed})$, La fin du Paléolithique supérieur dans les Alpes du nord françaises et le Jura méridional, vol. 50, Mémoire de la Société préhistorique française, Paris, pp 73-86.

Drucker DG, Bridault A, Cupillard C, Hujic A, Bocherens H (2011a) Evolution of habitat and environment of red deer (Cervus elaphus) during the Late-glacial and early Holocene in eastern France (French Jura and the western Alps) using multi-isotope analysis $\left(\delta^{13} \mathrm{C}, \delta^{15} \mathrm{~N}, \delta^{18} \mathrm{O}, \delta^{34} \mathrm{~S}\right)$ of archaeological remains. Quatern Int 245:268-278. https://doi.org/10.1080/10256010903388410. 
Drucker DG, Kind CJ, Stephan E (2011b) Chronological and ecological information on Lateglacial and early Holocene reindeer from northwest Europe using radiocarbon (14C) and stable isotope $\left({ }^{13} \mathrm{C},{ }^{15} \mathrm{~N}\right)$ analysis of bone collagen: case study in southwestern Germany. Quatern Int 245(2):218-224. https://doi.org/10.1016/j.quaint.2011.05.007.

Drucker DG, Bridault A, Cupillard, C (2012) Environmental context of the Magdalenian settlement in the Jura Mountains using stable isotope tracking $\left({ }^{13} \mathrm{C},{ }^{15} \mathrm{~N},{ }^{34} \mathrm{~S}\right)$ of bone collagen from reindeer (Rangifer tarandus). Quatern Int 272-273:268-278. https://doi.org/10.1016/j.quaint.2012.05.040.

Drucker DG, Stevens RE, Germonpré M, Sablin MV, Bocherens H (2018) Collagen stable isotopes provide insights into the end of the mammoth steppe in the central East European plains during the Epigravettian. Quaternary Res 90:457-469. https://doi.org/10.1017/qua.2018.40.

Fry B, Scalan RS, Winters JK, Parker PL, (1982) Sulphur uptake by salt grasses, mangroves, and seagrasses in anaerobic sediments. Geochim Cosmochim Ac 46:1121-1124. https://doi.org/10.1016/0016-7037(82)90063-1.

Gröcke DR, Sauer PE, Bridault A, Drucker DG, Germonpré M, Bocherens H (2017) Hydrogen isotopes in Quaternary mammal collagen from Europe. J Archaeol Sci Rep 11:12-16. https://doi.org/10.1016/j.jasrep.2016.11.020

Groscheová H, Novák M, Alewell C (2000) Changes in the $\delta^{34} S$ ratio of pore-water sulfate in incubated Sphagnum peat. Wetlands 20:62-69. https://doi.org/10.1672/02775212(2000)020[0062:CITSRO]2.0.CO;2

Hajdas I, Bonani G, Furrer H, Mäder A, Schoch W (2007) Radiocarbon chronology of the mammoth site at Niederweningen, Switzerland: results from dating bones, teeth, wood and peat. Quatern Int 164-165:98-105. https://doi.org/10.1016/j.quaint.2006.10.007. Heaton THE (1999) Spatial, Species, and Temporal Variations in the ${ }^{13} \mathrm{C} /{ }^{12} \mathrm{C}$ Ratios of $\mathrm{C}_{3}$ Plants: Implications for Palaeodiet Studies. J Archaeol Sci 26(6):637-649. https://doi.org/10.1006/jasc.1998.0381

Hedges, REM, Stevens, RE, Kock PL (2005) Isotopes in bones, in: Leng MJ (Ed), Isotopes in palaeoenvironmental research, vol. 10, Developments in palaeoenvironmental research, Dordrecht, pp 117-145.

Hemming S. 2004. Heinrich events: massive late Pleistocene detritus layers of the North Atlantic and their global climate imprint. Reviews of Geophysics 42: 1-43.

Higham TG, Jacobi RM, Bronk Ramsey C (2006) AMS radiocarbon dating of ancient bone using ultrafiltration. Radiocarbon 48(2):179-195. https://doi.org/10.1017/S0033822200066388. 
Hobbie E, Macko SA, Shugart HH (1998) Patterns of N dynamics and N isotopes during primary succession in Glacier Bay, Alaska. Cheml Geol 152:3-11. https://doi.org/10.1016/S0009-2541(98)00092-8.

Hobbie EA, Jumpponen A, Trappe J (2005) Foliar and fungal 15N:14N ratios reflect development of mycorrhizae and nitrogen supply during primary succession: testing analytical models. Oecologia 146:258-268. https://doi.org/10.1007/s00442-005-0208Z.

Ivy-Ochs S (2015) Glacier variations in the European Alps at the end of the last glaciation. Cuadernos de Investigación Geográfica 41(2):295-315. https://doi.org/10.18172/cig.2750.

Ivy-Ochs, S, Kerschner H, Kubik, PW, Schlüchter C. (2006) Glacier response in the European Alps to Heinrich Event 1 cooling: the Gschnitz stadial. J. Quaternary Sci 21: 115-130. ISSN 0267-8179.

Ivy-Ochs, S, Schäfer J, Kubik PW, Synal H-A, Schlüchter C (2004) The timing of deglaciation on the northern Alpine foreland (Switzerland). Eclogae Geol Helv 97:4755. https://doi.org/10.1007/s00015-004-1110-0.

Jonasson S, Michelsen A, Schmidt IK (1999) Coupling of nutrient cycling and carbon dynamics in the Arctic; integration of soil microbial and plant processes. Appl. Soil Ecol 11:135- 146. https://doi.org/10.1016/S0929-1393(98)00145-0.

Jones JR, Richards MP, Reade H, de Quiros FB, Marin-Arroyo AB (2018) Multi-Isotope investigations of ungulate bones and teeth from El Castillo and Covalejos caves (Cantabria, Spain): Implications for paleoenvironment reconstructions across the Middle-Upper Palaeolithic transition. J Archaeol Sci Rep 23:1029-1042. https://doi.org/10.1016/j.jasrep.2018.04.014

Julien M-A, Bocherens H, Burke A, Drucker DG, Patou-Mathis M, Krotova O, Péan S (2012) Were European steppe bison migratory? ${ }^{18} \mathrm{O},{ }^{13} \mathrm{C}$ and $\mathrm{Sr}$ intra-tooth isotopic variations applied to a palaeoethological reconstruction. Quaternary Int, 271:106-119. https://doi.org/10.1016/j.quaint.2012.06.011.

Kohn MJ (2010) Carbon isotope compositions of terrestrial C3 plants as indicators of (paleo)ecology and (paleo)climate. P Natl Acad Sci USA 107(46):19691-19695. https://doi.org/10.1073/pnas.1004933107

Krouse HR (1980) Sulfur isotopes in our environment, in: Fritz P, Fontes JC (Eds), Handbook of Environmental Isotope Geochemistry, Amsterdam, pp.435-471.

Larter NC, Gates CC (1991) Diet and habitat selection of wood bison in relation to seasonal changes in forage quantity and quality. Can Jo Zool 69:2677-2685 https://doi.org/10.1139/z91-376. 
Leesch, D (1997) Hauterive-Champréveyres. Un campement magdalénien au bord du lac de Neuchâtel. Cadre chronologique et culturel, mobilier et structures, analyse spatiale (secteur 1). Archéologie neuchâteloise, 19, Office et musée cantonal d'archéologie, Neuchâtel.

Leesch D, Müller W (2012) Neue Radiokarbondaten an Knochen, Zähnen und Geweih aus Magdalénien-Fundstellen der Schweiz und ihre Bedeutung für die Stellung des Magdalénien innerhalb des Spätglazials. Jahrbuch der Archäologie Schweiz 95:117126. https://doi.org/10.5169/seals-392487.

Leesch D, Cattin, M-I, Müller W (2004) Témoins d'implantations magdaléniennes et aziliennes sur la rive nord du lac de Neuchâtel. Archéologie neuchâteloise, 31, Office et musée cantonal d'archéologie, Neuchâtel.

Leesch D, Müller W, Nielsen E, Bullinger J (2012) The Magdalenian in Switzerland: Recolonization of a newly accessible landscape. Quatern Int 272-273:191-208 doi:10.1016/j.quaint.2012.04.010.

Leesch D, Bullinger J, Müller W (2019) Vivre en Suisse il y a 15000 ans. Le Magdalénien. Bâle, Archéologie suisse.

Longin R (1971) New method of collagen extraction for radiocarbon dating. Nature 230(5291):241-2. https://doi.org/10.1038/230241a0

Lotter AF (1999) Late-glacial and Holocene vegetation history and dynamics as shown by pollen and plant macrofossil analyses in annually laminated sediments from Soppensee, central Switzerland. Veget Hist Archaeobot 8: 165-184. https://doi.org/10.1007/BF02342718.

Lotter AF, Heiri O, Brooks S, van Leeuwen JFN, Eicher U, Ammann B (2012) Rapid summer temperature changes during Termination 1a: high-resolution multi-proxy climate reconstructions from Gerzensee (Switzerland). Quaternary Sci Rev 36:103-113. https://doi.org/10.1016/j.quascirev.2010.06.022.

Liu Y, He N, Wen X, Xu L, Sun X, Yu G, Liang L, Schipper LA (2018) The optimum temperature of soil microbial respiration: patterns and controls. Soil Biol Biochem 121:35-42.

Magny M (2013) Climatic and environmental changes reflected by lake-level fluctuations at Gerzensee from 14,850 to 13,050 yr BP. Palaeogeogr Palaeocl 391:33-39. https://doi.org/10.1016/j.palaeo.2012.05.003

Magny M, Aalbersberg G, Bégeot C, Benoit-Ruffaldi P, Bossuet G, Disnar JR, Heiri O, Laggoun-Defarge F, Mazier F, Millet L, Peyron O, Vannière B, Walter-Simmonnet AV (2006) Environmental and climatic changes in the Jura mountains (eastern France) during the Lateglacial-Holocene transition: a multiproxy record from Lake Lautrey. Quaternary Sci Rev 25:414-445. https://doi.org/10.1016/j.quascirev.2005.02.005. 
Maier A (2015) The Central European Magdalenian: Regional Diversity and Internal Variability, Springer Netherlands, Dordrecht.

Mandernack KW, Lynch L, Krouse HR, Morgan MD (2000) Sulfur cycling in wetland peat of the New Jersey pinelands and its effect on stream water chemistry. Geochim Cosmochim Ac 64:3949-64. https://doi.org/10.1016/S0016-7037(00)00491-9.

Morel P, Hug B, (1996) Découverte d'un crâne tardiglaciaire de rhinocéros laineux Coelodonta antiquitatis (Blumenbach 1799) dans le lac de Neuchâtel, au large de Vaumarcus (NE). Paléontologie et conservation. Bulletin de la Société neuchâteloise des Sciences naturelles 119:101-110.

Müller W (2013) Le site magdalénian de Monruz, 3. Acquisition, traitement et consommation des ressources animales. Archéologie neuchâteloise, 49, Office et musée cantonal d'archéologie, Neuchâtel.

Müller W, Leesch D (2011) Einige Neubestimmungen aus der Magdalénien-Fundstelle Hollenberg-Höhle 3 bei Arlesheim (Basel-Landschaft) und daraus folgende Überlegungen zur Nutzung der Höhle. Jahrbuch der Archäologie Schweiz 94:7-20. https://doi.org/ 10.5169/seals-179208.

Müller W, Leesch D, Bullinger J, Cattin M-I, Plumettaz N (2006) Chasse, habitats et rythme des déplacements: réflexions à partir des campements magdaléniens de Champréveyres et Monruz (Neuchâtel, Suisse). Bull Soc préhist fr 103(4):741-752.

Napierala H (2008) Die Tierknochen aus dem Kesslerloch. Neubearbeitung der paläolitischen Fauna. Beiträge zur Schaffhauser Archäologie 2. Baudepartement des Kantons Schaffhausen, Kantonsarchäologie, Schaffhausen.

Nehlich O (2015) The application of sulphur isotope analyses in archaeological research: A review. Earth-Sci Rev 142:1-17. https://doi.org/10.1016/j.earscirev.2014.12.002.

Nehlich O, Richards MP (2009) Establishing quality criteria for sulphur isotope analysis of archaeological bone collagen. Archaeol Anthrop Sci 1:59-75. https://doi.org/10.1007/s12520-009-0003-6

Newton R, Bottrell S (2007) Stable isotopes of carbon and sulphur as indicators of environmental change: past and present. J Geol Soc 164:691-708, https://doi.org/10.1144/001676492006-101.

Nielsen EH (2013) Response of the Lateglacial fauna to climatic change. Palaeogeogr Palaeocl 391:99-110.https://doi.org/10.1016/j.palaeo.2012.12.012

Nitsch EK, Lamb AL, Heaton THE, Vaiglova P, Fraser R, Hartman G, Moreno-Jiménex, López-Piñeiro A, Peña-Abades D, Fairbairn A, Eriksen J, Bogaard A (2019) The Preservation and Interpretation of $\delta^{34} S$ Values in Charred Archaeobotanical Remains. Archaeometry 61(1):161-178. https://doi.org/10.1111/arcm.12388. 
Orchard VA, Cook FJ (1983). Relationship between soil respiration and soil moisture. Soil Biol Biochem 15(4):447-453.

Pelligrini M, Donahue RE, Chenery C, Exans J, Lee-Thorp J, Montgomery J, Mussi M (2008) Faunal migration in late-glacial central Italy: implications for human resource exploitation. Rapid Commun Mass Sp 22(11):1714-1726. https://doi.org/10.1002/rcm.3521

Pryor AJ, Stevens RE, Pike AWG (2016) Seasonal mobility of the adult horse killed by hunters at Klementowice. In: Wisniewski, T (ed) Klementowice. A Magdalenian site in Eastern Poland. Lublin, PL, Instytut Archeologii Uniwersytetu Marie Curie Sklodowskiej pp. 298-304.

Rabanus-Wallace M, Wooller M, Zazula G, Shute E, Jahren AH, Kosintsev P, Burns JA, Breen J, Llamas B, Cooper A (2017) Megafaunal isotopes reveal role of increased moisture on rangeland during late Pleistocene extinctions. Nat Ecol Evol 1:0125. https://doi.org/10.1038/s41559-017-0125

Rasmussen SO, Bigler M, Blockley SP, Blunier T, Buchardt SL, Clausen HB, Cvijanovic I, Dahl-Jensen D, Johnsen SJ, Fischer H, Gkins V, Guillevic M, Hoek WZ, Lowe JJ, Pedro JB, Popp T, Seierstad IK, Steffensen JP, Svensson AM, Vallelonga P, Vinther BM, Walker MJC, Wheatley JJ, Winstrup M (2014) A stratigraphic framework for abrupt climatic changes during the Last Glacial period based on three synchronized Greenland ice-core records: refining and extending the INTIMATE event stratigraphy. Quaternary Sci Rev 106:14-28 https://doi.org/10.1016/j.quascirev.2014.09.007.

Reade H, Tripp JA, Charlton S, Grimm SB, Sayle KL, Fensome A, Higham TFG, Barnes I, Stevens RES (2020) Radiocarbon chronology and environmental context of Last Glacial Maximum human occupation in Switzerland. Sci Rep 10:4694 https://doi.org/10.1038/s41598-020-61448-7

Renssen, H, Vandenberghe $\mathrm{J}$ (2003) Investigation of the relationship between permafrost distribution in NW Europe and extensive winter sea-ice cover in the North Atlantic Ocean during the cold phases of the Last Glaciation. Quaternary Sci Rev 22:209-223. https://doi.org/10.1016/S0277-3791(02)00190-7

Rey F, Gobet E, van Leeuwen JFN, Gilli A, van Raden UJ, Hafner A, Wey O, Rhiner J, Schmocker D, Zünd J, Tinner W (2017) Vegetational and agricultural dynamics at Burgäschisee (Swiss Plateau) recorded for 18,700 years by multi-proxy evidence from partly varved sediments. Veg Hist Archaeobot 26(6):571-586. https://doi.org/10.1007/s00334-017-0635-x deglaciation and vegetation dynamics since the Last Glacial Maximum at Moossee (Switzerland). Clim Past Discuss. https://doi.org/10.5194/cp-2019-121 
Robinson BW, Bottrell SH (1997) Discrimination of sulphate sources in pristine and polluted New Zealand river catchments using stable isotopes. Appl. Geochem. 12: 305-319. https://doi.org/10.1016/S0883-2927(96)00070-4.

Sayle KL, Brodie CR, Cook GT, Hamilton WD (2019) Sequential measurement of $\delta^{15} \mathrm{~N}, \delta^{13} \mathrm{C}$ and $\delta^{34} S$ values in archaeological bone collagen at the Scottish Universities Environmental Research centre (SUERC): A new analytical frontier. Rapid Commun Mass Spectrom. 33:1258-1266 https://doi.org/10.1002/rcm.8462

Schlüchter C, Bini A, Buoncristiani JF, Coutterand S, Ellwanger D, Felber M, Florineth D, Graf HR, Keller O, Kelly M, Schoeneich P (2010) Die Schweiz während des letzteiszeitlichen Maximum (LGM) 1:500 000. Bundesamt für Landestopografie Swisstopo, Wabern.

Schulze ED, Chapin FS, Gebauer G, (1994) Nitrogen nutrition and isotope differences among life forms at the Northern Treeline of Alaska. Oecologia 100:406-412. https://doi.org/10.1007/BF00317862.

Schweizer T, Schmid, E, Bay R (1959) Die «Kastelhöhle» im Kaltbrunnental, Gemeinde Himmelried (Solothurn). Jahrbuch für Solothurnische Geschichte 32: 1-88.

Sealy, J, Johnson M, Richards MP, Nehlich O (2014) Comparison of two methods of extracting bone collagen for stable carbon and nitrogen analysis: comparing whole bone demineralization with gelatinization and ultrafilitration. J Archaeol Sci 47:64-69. https://doi.org/10.1016/j.jas.2014.04.011.

Stark S (2007) Nutrient Cycling in the Tundra, in: Marschner P, Rengel Z (Eds), Nutrient Cycling in Terrestrial Ecosystems, vol 10, Soil Biology, Springer, Berlin.

Stevens RE, Hedges REM (2004) Carbon and nitrogen stable isotope analysis of northwest European horse bone and tooth collagen, 40,000 BP-present: palaeoclimatic interpretations. Quaternary Sci Rev 23: 977-991. https://doi.org/10.1016/j.quascirev.2003.06.024

Stevens RE, Jacobi R, Street M, Germonpré M, Conard NJ, Münzel SC, Hedges REM (2008) Nitrogen isotope analyses of reindeer (Rangifer tarandus), 45,000 BP to 9,000 BP: Palaeoenvironmental reconstructions. Palaeogeog Palaeocl 262:32-45. https://doi.org/10.1016/j.palaeo.2008.01.019

Stevens RE, Hermoso-Buxán XL, Marín-Arroyo AB, González-Morales MR, Straus LG (2014) Investigation of Late Pleistocene and Early Holocene palaeoenvironmental change at El Mirón cave (Cantabria, Spain): insights from carbon and nitrogen isotope analyses of red deer. Palaeogeogr Palaeocl 414:46-60. https://doi.org/10.1016/j.palaeo.2014.05.049 
Szpak P, Metcalfe JZ, Macdonald RA (2017) Best practices for calibrating and reporting stable isotope measurements in archaeology. J Archaeol Sci Rep 13:609616. https://doi.org/10.1016/j.jasrep.2017.05.007

Terberger T, Street M (2002) Hiatus or continuity? New results for the question of Pleniglacial settlement in Central Europe. Antiquity 76:691-698. https://doi.org/10.1017/S0003598X00091134.

Thew N, Hadorn P, Coope R (2009) Hauterive/Rouges-Terres. Reconstruction of Upper Palaeolithic and Early Mesolithic Natural Environments. Archéologie neuchâteloise, 44, Office et musée cantonal d'archéologie, Neuchâtel.

Thode HG (1991) Sulfur isotopes in nature and the environment: an overview, in: Krouse HR, Grinenko VA (Eds), Stable Isotopes: Natural and Anthropogenic Sulfur in the Environment, John Wiley and Sons: Chichester, pp. 1-26.

Trust BA, Fry B (1992) Stable sulphur isotopes in plants: a review. Plant Cell Environ 15:1105-10. https://doi.org/10.1111/j.1365-3040.1992.tb01661.x.

Vandenberghe J, French HM, Gorbunov A, Marchenko S, Velichko AA, Jin H, Cui Z, Zhang T, Wan X (2014) The Last Permafrost Maximum (LPM) map of the Northern Hemisphere: permafrost extent and mean annual air temperatures, 25-17 ka BP. Boreas 43: 652-666. https://doi.org/110.1111/bor.12070

Walker RW (1957) The sulfur cycle in grassland soils. Grass Forage Sci 12:10-18. https://doi.org/10.1111/j.1365-2494.1957.tb00086.x

Wehrli M, Tinner W, Ammann B (2007) 16,000 years of vegetation and settlement history from Egelsee (Menzingen, central Switzerland). The Holocene 17(6):747-761. https://doi.org/10.1177/0959683607080515

Weniger G-C (1989) The Magdalenian in Western Central Europe: Settlement Pattern and Regionality. J World Prehist 3(3):323-372. https://doi.org/10.1007/BF00975326 Wißing C, Rougier H, Baumann C, Comeyne A, Crevecoeur I, Drucker DG, GaudzinskiWindheuser S, Germonpré M, Gómez-Olivencia A, Krause J, Matthies T, Naito YI, Posth C, Semal P, Street M, Bocherens H. (2019) Stable isotopes reveal patterns of diet and mobility in the last Neandertals and first modern humans in Europe. Sci Rep 9: 4433. https://doi.org/10.1038/s41598-019-41033-3.

Wood RE, Bronk Ramsey C, Higham TG (2010) Refining background corrections for radiocarbon dating of bone collagen at ORAU. Radiocarbon 52(2): 600-611.

\section{References appearing only in figures and tables:}

Becker, D., Verheul, J., Zickel, M., Willmes, C. (2015): LGM paleoenvironment of Europe Map. CRC806-Database, DOI: 10.5880/SFB806.15 
Bodu P, Debout G, Dumarçay G, Leesch D, Valentin B (2009) Révision de la chronologie magdalénienne dans le Bassin parisien et alentours: nouveaux résultats, in: Valentin B (Ed), Paléolithique final et Mésolithique dans le Bassin parisien et ses marges. Habitats, sociétés et environnements, Projet collectif de recherche, Programmes P7, P8 et P10 Rapport d'activités pour 2009, Paris, pp. 91-99.

Bronk Ramsey, C. (2017) Methods for Summarizing Radiocarbon Datasets. Radiocarbon 59(6): 1809-1833.

North Greenland Ice Core Project members (2004) High-resolution record of Northern Hemisphere climate extending into the last interglacial period. Nature 431(7005): 147-151.

Reimer, P. J., Bard, E., Bayliss, A., Beck, J.W., Blackwell, P.G., Ramsey, C.B., Buck, C.E., Cheng, H., Edwards, R.L., Friedrich, M., Grootes, P.M., Guilderson, T.P., Haflidason, H., Hajdas, I., Hatté, C., Heaton, T.J., Hoffmann, D.L., Hogg, A.G., Hughen, K.A., Kaiser, K.F., Kromer, B., Manning, S.W., Niu, M., Reimer, R.W., Richards, D.A., Scott, E.M., Southon, J.R., Staff, R.A., Turney, C.S.M., van der Plicht, J. (2013), IntCal13 and Marine13 Radiocarbon Age Calibration Curves 050,000 Years cal BP. Radiocarbon 55(4): 1869-1887. 


\begin{tabular}{|c|c|c|c|c|c|c|c|c|c|c|}
\hline $\begin{array}{c}\text { Project } \\
\text { sample } \\
\text { code } \\
\end{array}$ & Species & Element & $\begin{array}{l}\text { Collagen } \\
\text { yield (\%) }\end{array}$ & $\begin{array}{l}\delta^{13} \mathrm{C} \\
(\% \circ)\end{array}$ & $\begin{array}{l}\mathbf{C} / \mathbf{N} \\
\text { ratio }\end{array}$ & AMS Code & ${ }^{14} \mathrm{C} B P$ & $\begin{array}{c}\text { Calibrated Age } \\
\text { BP } \\
(2 \sigma) \\
\end{array}$ & Time Period & Ref \\
\hline \multicolumn{11}{|c|}{ Kastelhöhle-Nord, upper horizon } \\
\hline \multirow{2}{*}{ UPN-232 } & \multirow{2}{*}{ Bos/Bison } & \multirow{2}{*}{ metacarpus } & 10.4 & -19.5 & 3.3 & OxA-V-2794-25C & $13,550 \pm 60$ & $16,566-16,107$ & GS-2.1a & 1 \\
\hline & & & not given & -18.8 & not given & ETH-45024 & $13,435 \pm 50$ & $16,350-15,965$ & GS-2.1a & 2 \\
\hline UPN-214 & Equus sp. & phalanx I & 2.8 & -21.1 & 3.2 & OxA-V-2754-48C & $12,880 \pm 50$ & $15,605-15,181$ & GS-2.1a & 1 \\
\hline UPN-218 & Equus sp. & carpal & 8.1 & -20.4 & 3.2 & OxA-V-2748-25C & $12,560 \pm 50$ & $15,142-14,529$ & GS-2.1a/Gl-1e & 1 \\
\hline \multirow{2}{*}{ UPN-212 } & \multirow{2}{*}{$\begin{array}{l}\text { Rangifer } \\
\text { tarandus }\end{array}$} & \multirow{2}{*}{ tibia } & 5.4 & -19.6 & 3.3 & OxA-V-2793-55C & $12,380 \pm 50$ & $14,764-14,138$ & Gl-1ed & 1 \\
\hline & & & not given & -18.9 & not given & ETH-45025 & $12,395 \pm 45$ & $14,780-14,160$ & Gl-1ed & 2 \\
\hline \multirow{2}{*}{ UPN-204 } & \multirow{2}{*}{$\begin{array}{l}\text { Rangifer } \\
\text { tarandus }\end{array}$} & \multirow{2}{*}{ radius } & 7.4 & -19.5 & 3.3 & OxA-V-2793-54C & $12,270 \pm 60$ & $14,740-14,129$ & Gl-1ed & 1 \\
\hline & & & not given & -19.8 & not given & ETH-45026 & $12,215 \pm 45$ & $14,265-13,967$ & Gl-1ed & 2 \\
\hline UPN-213 & $\begin{array}{l}\text { Rangifer } \\
\text { tarandus }\end{array}$ & $\begin{array}{c}\text { tibia, } \\
\text { cut-marked }\end{array}$ & 4.5 & -19.6 & 3.4 & OxA-V-2793-56C & $12,200 \pm 50$ & $14,260-13,935$ & Gl-1ed & 1 \\
\hline \multicolumn{11}{|c|}{ Monruz and Champréveyres Magdalenian } \\
\hline $\mathrm{n} / \mathrm{a}$ & Equus sp. & femur & not given & -20.3 & not given & OxA-20699 & $13,055 \pm 60$ & $15,874-15,349$ & GS-2.1a & 3 \\
\hline $\mathrm{n} / \mathrm{a}$ & Equus sp. & talus & not given & -20.5 & not given & OxA-20700 & $12,815 \pm 65$ & $15,562-15,092$ & GS-2.1a & 3 \\
\hline $\mathrm{n} / \mathrm{a}$ & Equus sp. & talus & not given & -20.4 & not given & OxA-20701 & $12,805 \pm 75$ & $15,585-15,053$ & GS-2.1a & 3 \\
\hline \multicolumn{11}{|c|}{ Champréveyres Early Azilian } \\
\hline UPN-240 & $\begin{array}{l}\text { Cervus } \\
\text { elaphus }\end{array}$ & metatarsal & 2.3 & -20.9 & 3.3 & OxA-V-2754-49 & $12,480 \pm 50$ & $15,023-14,284$ & GS-2.1a/GI-1e & 1 \\
\hline
\end{tabular}

Table 1. AMS radiocarbon determinations on bone collagen from the sites and levels discussed in the text, and as shown in Figure 2 . $\delta^{13} \mathrm{C}$ and $\mathrm{C} / \mathrm{N}$ ratio measured by IRMS as part of the radiocarbon dating procedure at the Oxford Radiocarbon Accelerator Unit. Calibration of radiocarbon age determinations was performed using OxCal 4.3 (Bronk Ramsey 2017) and the INTCAL13 dataset (Reimer et al. 2013). References (Ref) for dates: ${ }^{1}$ this study; ${ }^{2}$ Leesch and Müller, 2012; and ${ }^{3}$ Bodu et al., 2009. 


\begin{tabular}{|c|c|c|c|c|c|c|c|c|c|c|}
\hline Fauna & $\mathbf{n}$ & $\begin{array}{c}\text { Average } \\
\delta^{13} \mathrm{C} \\
(\% \circ) \\
\end{array}$ & $\begin{array}{l}\text { Max } \\
\delta^{13} \mathrm{C} \\
(\% 0) \\
\end{array}$ & $\begin{array}{l}\text { Min } \\
\delta^{13} \mathrm{C} \\
(\% 0) \\
\end{array}$ & $\begin{array}{c}\text { Average } \\
\delta^{15} \mathrm{~N} \\
(\%) \\
\end{array}$ & $\begin{array}{l}\text { Max } \\
\delta^{15} \mathrm{~N} \\
(\% 0) \\
\end{array}$ & $\begin{array}{l}\text { Min } \\
\delta^{15} \mathrm{~N} \\
(\% \circ) \\
\end{array}$ & $\begin{array}{c}\text { Average } \\
\delta^{34} \mathrm{~S} \\
(\% \circ) \\
\end{array}$ & $\begin{array}{l}\text { Max } \\
\delta^{34} S \\
(\% 0) \\
\end{array}$ & $\begin{array}{l}\text { Min } \\
\delta^{34} S \\
(\% 0)\end{array}$ \\
\hline \multicolumn{11}{|c|}{ Kastelhöhle Nord, upper horizon } \\
\hline Bos/Bison & 6 & $-19.9 \pm 0.2$ & -19.7 & -20.1 & $3.2 \pm 0.5$ & 4.0 & 2.6 & $-6.1 \pm 1.9$ & -4.2 & -10.0 \\
\hline Equus sp. & 5 & $-20.8 \pm 0.4$ & -20.2 & -21.3 & $1.6 \pm 0.5$ & 2.3 & 0.7 & $-2.3 \pm 0.9$ & -1.2 & -3.8 \\
\hline Rangifer tarandus & 10 & $-19.7 \pm 0.3$ & -19.4 & -20.3 & $2.8 \pm 0.4$ & 3.5 & 2.3 & $-5.5 \pm 1.5$ & -1.3 & -7.1 \\
\hline \multicolumn{11}{|l|}{ Monruz } \\
\hline Equus sp. & 7 & $-21.0 \pm 0.2$ & -20.8 & -21.4 & $1.8 \pm 0.6$ & 2.9 & 1.1 & $-12.3 \pm 5.2$ & -3.6 & -19.8 \\
\hline Rangifer tarandus & 4 & $-19.8 \pm 0.2$ & -19.6 & -20.1 & $2.8 \pm 0.2$ & 3.2 & 2.6 & $-13.8 \pm 2.9$ & -10.3 & -17.3 \\
\hline \multicolumn{11}{|l|}{ Champréveyres } \\
\hline Cervus elaphus & 1 & -20.7 & - & - & 2.4 & - & - & $(-7.2)$ & - & - \\
\hline
\end{tabular}

Table 2. Summary statistics for carbon, nitrogen and sulphur isotopic ratios for each species and archaeological site. Each sample was analysed in duplicated by IRMS at the Scottish Universities Environmental Research Centre. Data in () was deemed unreliable based on standard quality control criteria. Full results are presented in the Supplementary Information 1. 
877 Figure 1: Map showing the location of Monruz, Champréveyres and Kastelhöhle-Nord.

878 Bedrock geology is from the International Geological Map of Europe (IGME 5000; Asch

879 2005). Black line indicates present day country borders. White hatching indicates

880 reconstructed limits of Last Glacial Maximum (LGM) ice sheet extent from Becker et al.

881 (2015). Symbols indicate archaeological sites from which isotopic data used in our

882 discussion comes (full data in Supplementary Information 5), from areas that were covered

883 by ice at the LGM (pink circles) and those in areas that remained ice free throughout the

884 LGM (black squares). Inset: location of Switzerland in Europe indicated by red box.

886 Figure 2. Calibrated AMS radiocarbon determinations on faunal bone collagen from sites

887 discussed in the text. Calibration was performed using OxCal 4.3 (Bronk Ramsey 2017) and

888 the INTCAL13 dataset (Reimer et al. 2013) and plotted with the Last Glacial period

889 INTIMATE event stratigraphy and NGRIP ice core $\delta^{18} \mathrm{O}$ values values (top; North Greenland

890 Ice Core Project members. 2004; Rasmussen et al., 2014). Purple = Bos/Bison, blue =

891 horse, red $=$ reindeer, green $=$ red deer. Kastelhöhle-Nord dates from this study (OxA codes)

892 and Leesch and Müller (2012; ETH codes); Monruz and Champréveyres Magdalenian dates

893 from Bodu (2009); Champréveyres Azilian dates from this study. Symbols * ${ }^{\star}$, and

$894 \Delta$ indicate date is on same bone specimen.

895

896 Figure 3. $\delta^{13} \mathrm{C}, \delta^{15} \mathrm{~N}$, and $\delta^{34} \mathrm{~S}$ values of Kastelhöhle-Nord upper horizon samples. Overlap

897 in values can be seen between Bos/Bison (green triangles) and reindeer (Rangifer tarandus,

898 orange circles), while horse (Equus sp., blue squares) are dissimilar in their isotopic values.

899 Enlarged symbols represent directly dated samples reported in Figure 2.

900

901 Figure 4. $\delta^{13} \mathrm{C}, \delta^{15} \mathrm{~N}$, and $\delta^{34} S$ values from reindeer (Rangifer tarandus, circles) and horse

902 (Equus sp, triangles) from Kastelhöhle-Nord upper horizon (yellow) and Monruz (green).

$903 \delta^{13} \mathrm{C}$ and $\delta^{15} \mathrm{~N}$ values cluster by species, while $\delta^{34} \mathrm{~S}$ values cluster by location.

904

905 Figure 5. $\delta^{15} \mathrm{~N}$ (middle) and $\delta^{34} S$ (bottom) isotope values from LGM and Lateglacial fauna 906 (Bos/Bison, horse, red deer, reindeer) from the French and Swiss Jura, western Alps and 907 Swiss Plateau (full data in Supplementary Information 5). INTIMATE event stratigraphy and 908 NGRIP ice core $\delta^{18} \mathrm{O}$ values (top; North Greenland Ice Core Project members. 2004; 909 Rasmussen et al., 2014). Black symbols indicate samples from locations that remained ice-

910 free throughout the LGM, pink symbols indicate samples from locations that were ice- 
911 covered at the LGM, as displayed in Figure 1. Circles indicate directly dated specimens (by

912 radiocarbon), triangles indicate context dated specimens, where age has been inferred from

913 dates on other faunal specimens from the same site/stratigraphic context.

914 


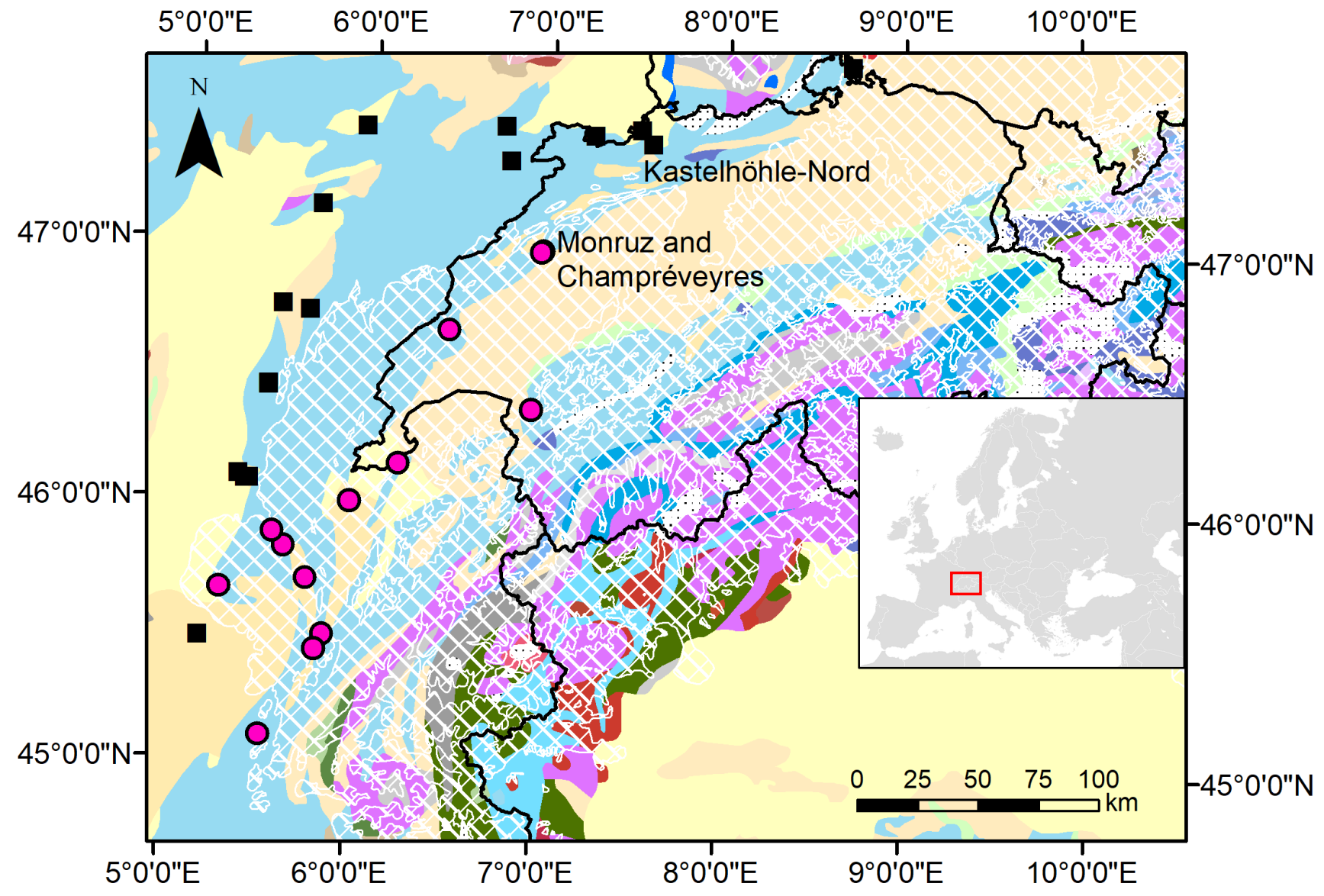

\section{Bedrock geology}

\begin{tabular}{|c|c|c|c|}
\hline amphibolite & granite & meta-sediment group & sand \\
\hline basalt & granulite & mica schist & sandstone \\
\hline carbonates, consolidated & gravel & migmatite/anatexite & shale/slate \\
\hline clay & greenschist & mudstone & siltstone \\
\hline claystone & limestone & phyllite & syenite \\
\hline conglomerate & marble & plutonic ultramafic group & tholeiitic basalt \\
\hline diorite & marlstone & quartzite & tonalite \\
\hline dolomite/dolostone & meta-rhyolite group & rhyodacite & undifferentiated \\
\hline gneiss & meta-sandstone & rhyolite & \\
\hline
\end{tabular}




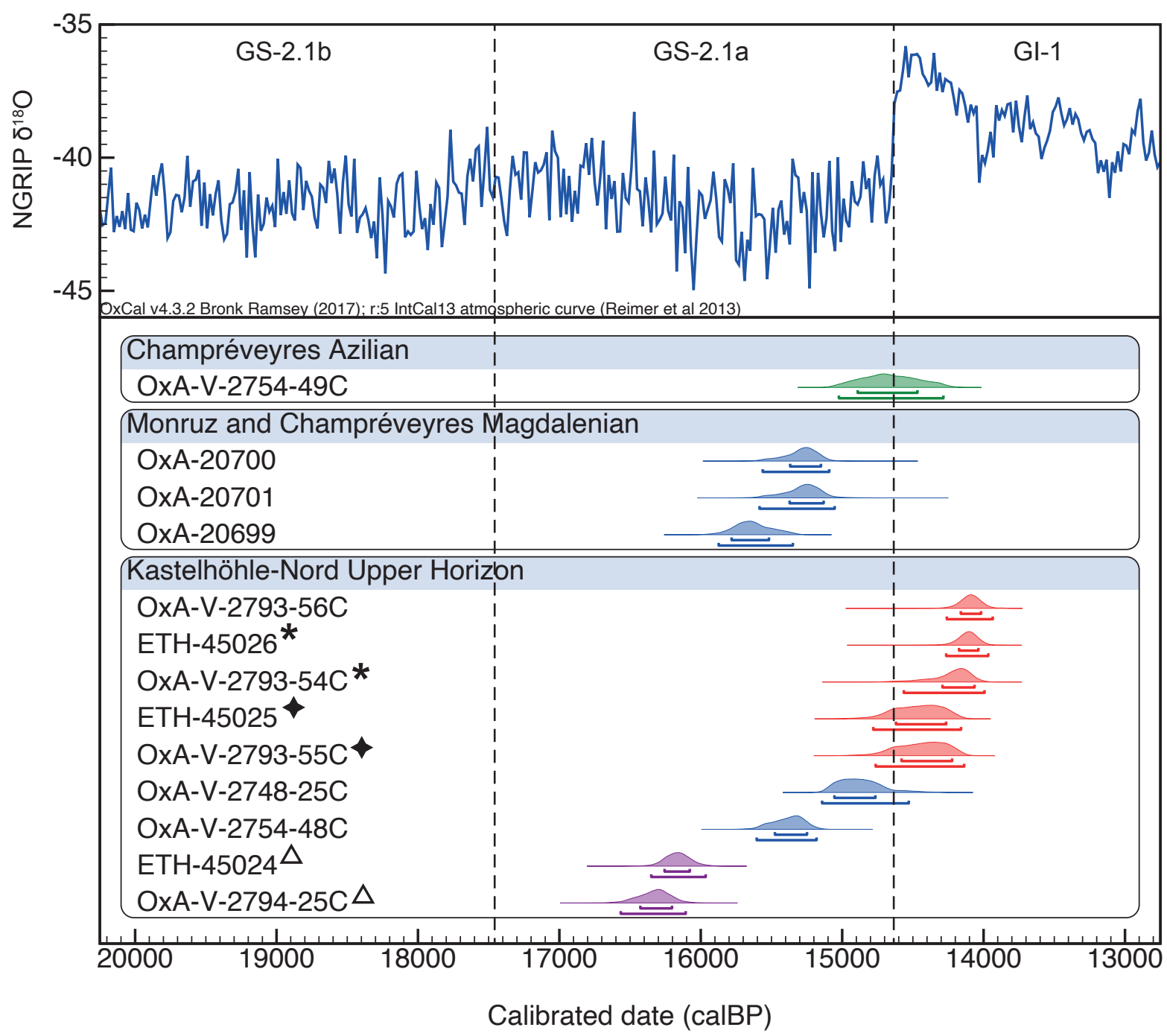




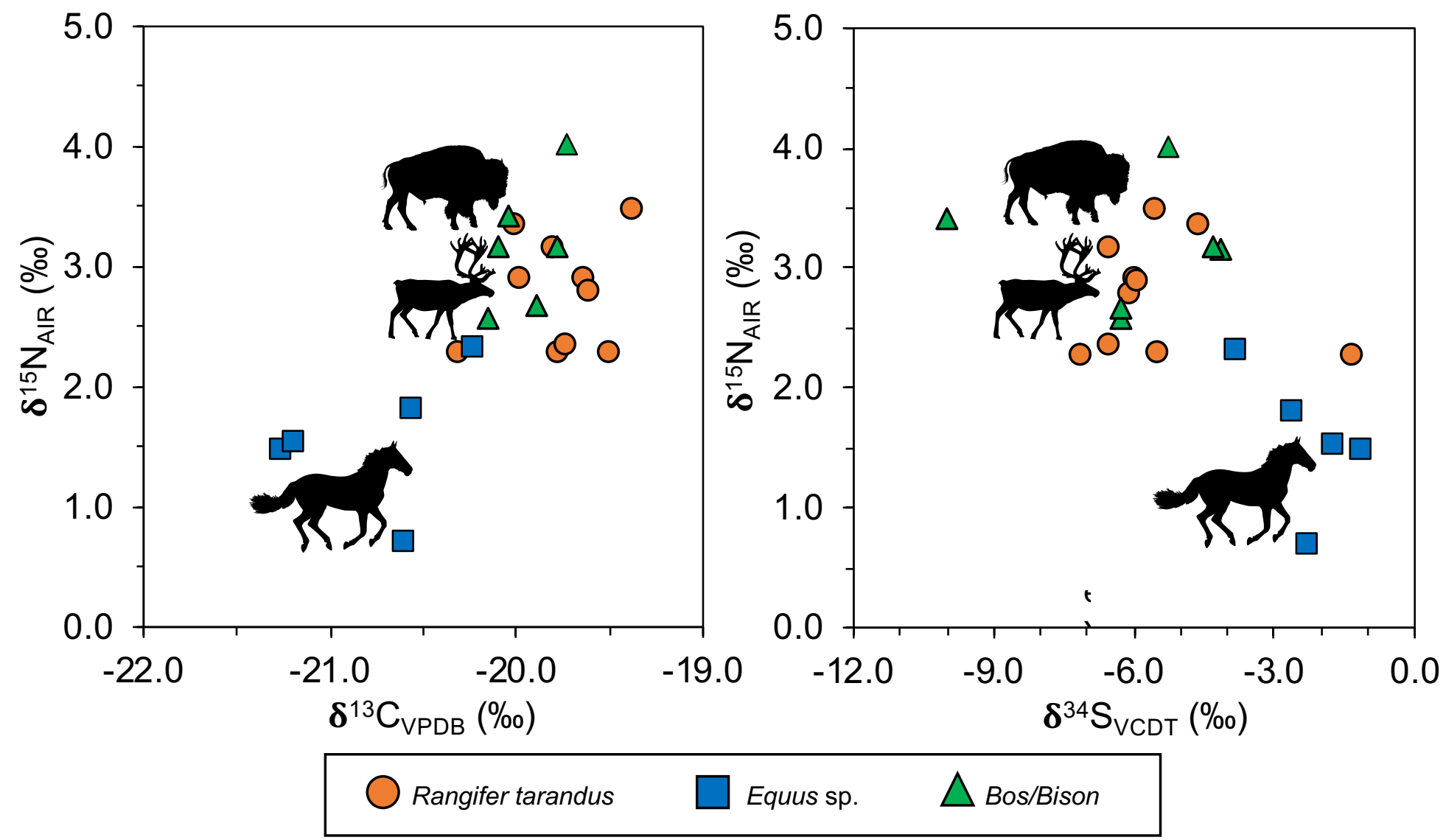




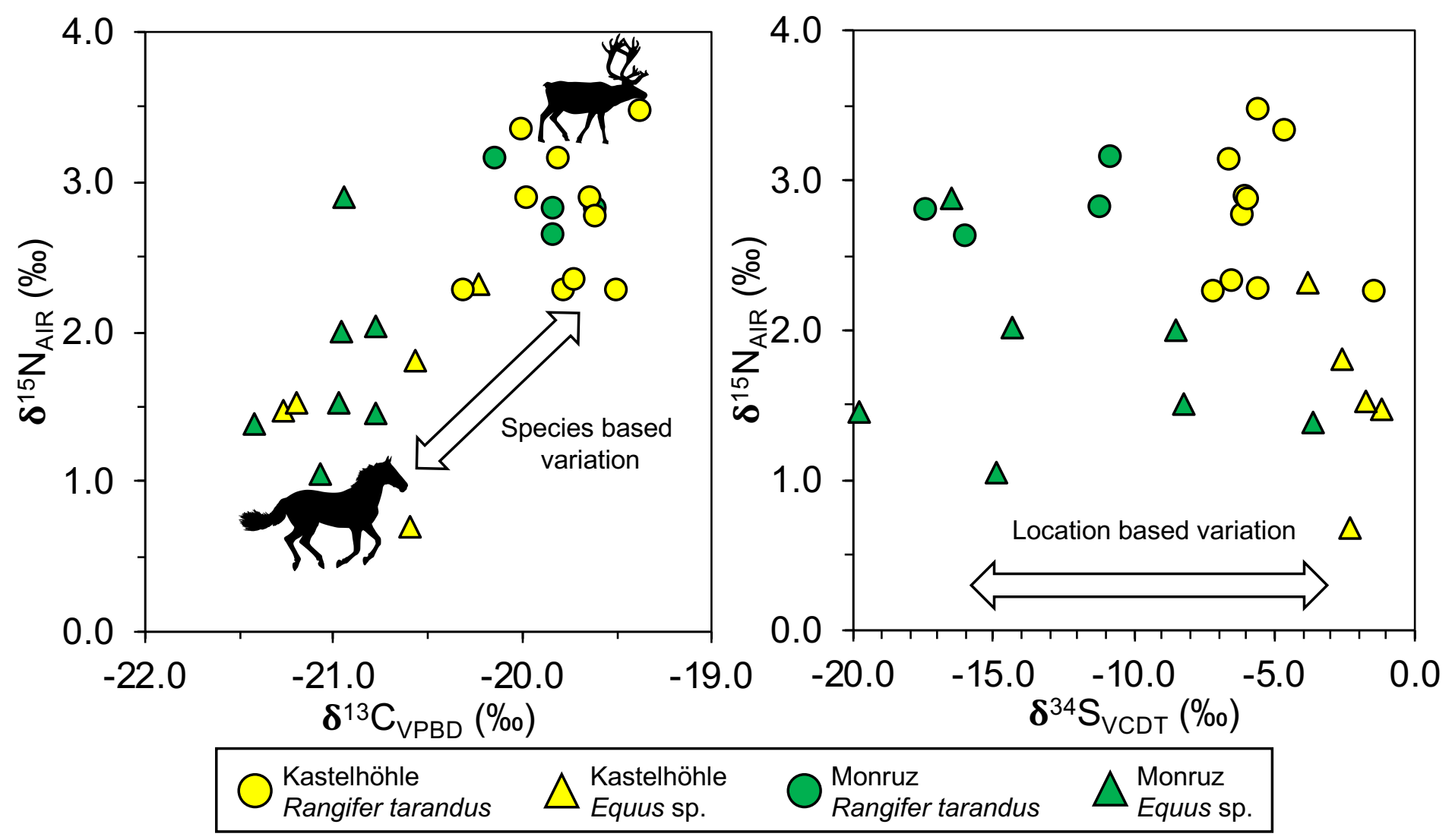




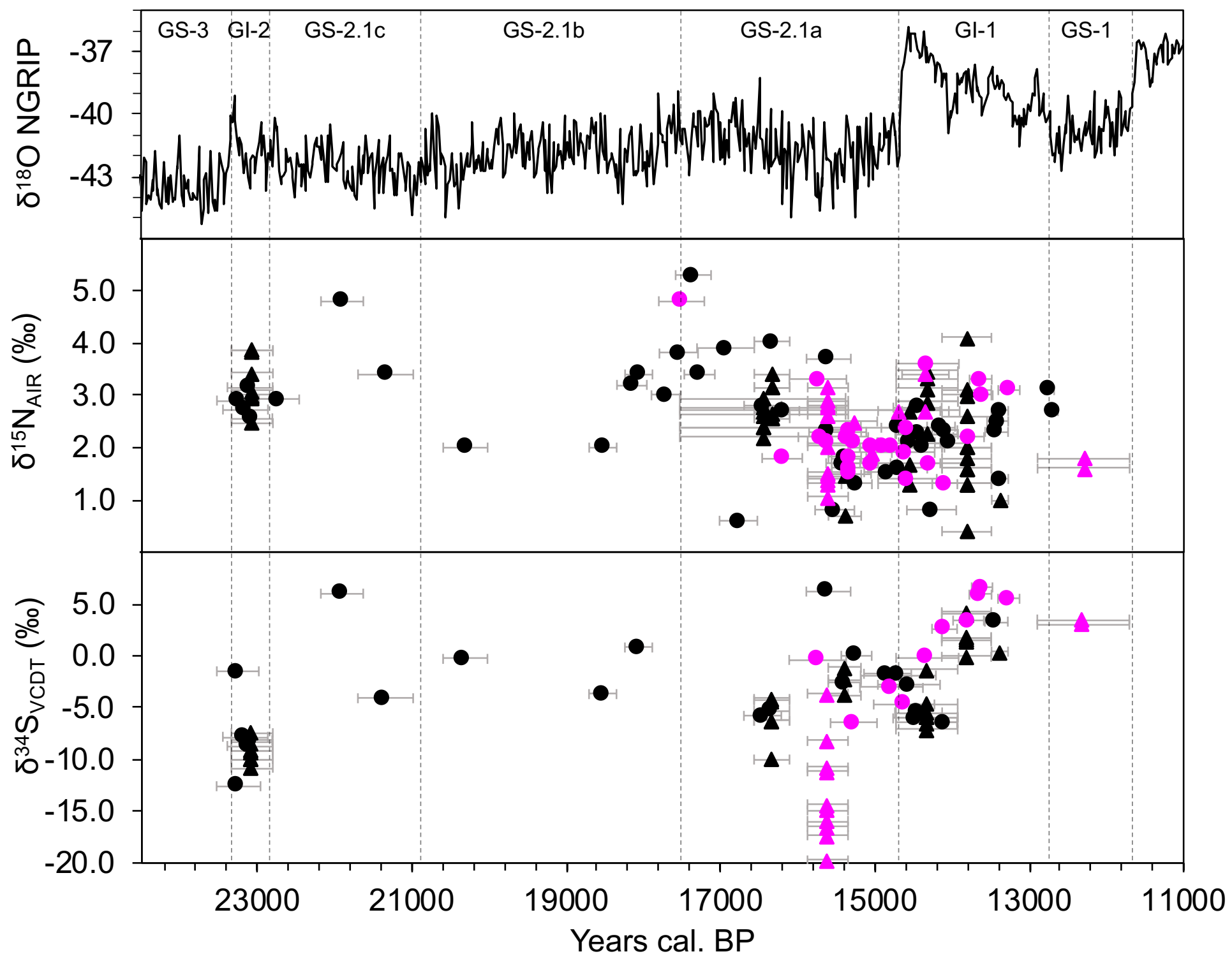

Ice-free at LGM (direct date) 